\title{
JOB SATISFACTION AND PREFERENCES REGARDING JOB CHARACTEREISTICS OF VOCATIONALS AND MASTER CRAFTSMAN SCHOLARS AND HORTICULTURE STUDENTS IN GERMANY
}

\author{
Stephan G.H. MEYERDING
}

\author{
Address: \\ Center for Business Management in Horticulture and Applied Research, Gottfried Wilhelm Leibniz University Hanover, \\ Germany. \\ E-mail: meyerding@zbg.uni-hannover.de
}

\begin{abstract}
Labour costs account for $40 \%$ of all the costs in German horticulture. Employee satisfaction has a significant impact on the economic and social sustainability of horticultural companies. Traditional linear relationships between environmental characteristics and subjective job satisfaction have been assumed in psychological research. Warr (2007) challenged this conception with the non-linear vitamin model. The present study examines the possibility of non-linear relationships between job characteristics and job satisfaction. For this purpose, a survey was carried out using an online and a paper-and-pencil questionnaire from August 2013 to February 2015. In addition, the preferences of employees $(N=229)$, vocational and master craftsman scholars $(N=205)$ and students of horticulture science $(N=204)$ regarding job characteristics were examined. This article focuses on the later two. The relationships between characteristic values and work and life satisfaction are analysed and the results of the three groups are compared. The strongest relationships with job satisfaction can be observed for vocational and master craftsman scholars for the job features emotional dissonance and considerate leadership. Additionally, employers' fair treatment of the society as a whole has a strong impact on job satisfaction. The salary can be found only in the lower middle range. The data support the assumption of non-linear relationships between job characteristic values and satisfaction. Furthermore, the personal characteristics of the study participants are included in the analysis. The study indicates a change in the preference structure of employees, who in the future would prefer a good work-life balance in particular as well as other "soft" factors.
\end{abstract}

Keywords: employee well-being, horticulture, human resources management, job satisfaction, social sustainability JEL: J28, M54, J43

\section{INTRODUCTION}

Personnel costs account for about $40 \%$ of all the costs in German horticulture. The importance of human resource management will increase in most industrialized countries in the wake of demographic change, which is often associated with a war-for-talents and a more diverse workforce (Montén, 2011; Meyerding, 2015a). Employee-related issues will be the cause of fundamental transformation processes in the next two decades in German companies of all industries (Claßen and von Kyaw, 2007, p. 17) and are considered as a key factor in the future success of horticulture in Germany (Schreiner et al., 2013, pp. 73-76). Another aspect is the increasing attention of consumers and society to the social dimensions of sustainability, the potential of which has not yet been addressed by a number of sustainability assessment systems in agriculture. Subjective job satisfaction can be used as a key indicator of social sustainability and has many advantages compared with objectively quantified indicators (Meyerding, 2015a; 2015b).

"In essence, stable well-being is when individuals have the psychological, social and physical resources they need to meet a particular psychological, social and/or physical challenge. When individuals have more challenges than resources, the see-saw dips, along with their well-being, and vice-versa." (Dodge et al., 2012, p. 230; Meyerding, 2015a) Subjective satisfaction can be measured context-free as life satisfaction and contextbased as job satisfaction and facet-specific, for example satisfaction with one's salary.

There are diverse approaches to the measurement and understanding of psychological satisfaction at work (von Rosenstiel, Kehr and Maier, 2000). If job satisfaction is to be measured by the subjective assessment of characteristic values of different facets of the job, it is essential to determine which facets (aspects) are to be included in the valuation model. Specifically, it is necessary to decide whether environmental characteristics (facets of the job) alone or additional personal characteristics should be included in the analysis (Warr, 2013). One way to evaluate job satisfaction is to use Herzberg's two-factor model (Herzberg, Mausner and Synderman 1959; Herzberg 1966). For example, Bitsch and Hogberg (2005) used parts of Herzberg's model in a qualitative study of US horticulture based on 31 interviews. More recently, Reiche and Sparke (2012) performed a quantitative study among 446 specialized vocational and master craftsman scholars that followed an innovative analytical approach but was mainly based on Herzberg's model (Meyerding, 2015a). Although the use 
of Herzberg's model (Herzberg, Mausner and Synderman, 1959) is widespread in business administration, the personnel management literature and relevant studies, it is not supported by empirical studies (von Rosenstiel, Kehr and Maier, 2000). To the author's knowledge, there was no quantitative study on German horticulture that is not based on Herzberg's model and considers the possibility of non-linear relationships (Warr, 1987; de Jong and Schaufeli 1998; van Vegchel de Jonge and Landsbergis, 2005).

This empirical quantitative study examines the relationships between 28 job aspects and job and life satisfaction for vocational and master craftsman scholars in German horticulture. In addition, Warr's vitamin model (Warr, 1987; 2007) is tested. Furthermore, the different preference structures between generations regarding the job aspects investigated become visible. For this purpose, more than 600 complete records of more than 1,300 study participants were examined. Three groups - employees, vocational and master craftsman scholars and students of horticultural sciences - each with over 200 full records, were evaluated separately. This article focuses on the vocational and master craftsman scholars and students of horticulture science. The theoretical background and the methodology of the present study are based on the latest version of Warr's vitamin model (Warr, 2007), which provides 12 job characteristics (vitamins) and their hypothetical utility function. The utility functions describe the nature of the relationship of job characteristics and different forms of satisfaction.

Previous studies in horticulture (Bitsch and Hogberg, 2005; Reiche and Sparke, 2012) have been based on the Herzberg model (Herzberg, 1966; Herzberg, Mausner and Synderman, 1959) and have assumed linear relationships between job characteristics and job satisfaction. In recent decades, two theoretical approaches have been successful in guiding empirical research: the job characteristics model (Hackman and Oldham, 1975) and the demand control support model (Karasek, 1979). Although these models differ in purpose and complexity, they assume linear relationships too, although different studies (de Jong, Schaufeli and Furda, 1995; Warr 1990; de Jong and Schaufeli, 1998; de Jonge et al., 2000) have partially supported the assumed types of utility functions of the vitamin model (de Jong and Schaufeli, 1998). However, De Jonge and Schaufeli (1998), who tested the vitamin model, used an earlier version of the model with nine vitamins (Warr, 1994), and the current model contains twelve vitamins (Warr 2007; Meyerding, 2015a). The current model was tested by Meyerding (2015a), whose study showed the validity of the model for employees in horticulture. The utility functions can differ between subgroups. For this reason, the individual utility functions are analysed for vocational and master craftsman scholars.

The objective of this study is to identify the relationships between job aspects and job satisfaction in German horticulture and to verify the assumed utility functions as well as indicating the effects of personal characteristics. At the same time, it will demonstrate that the job satisfaction indicator based on the survey method used here covers the most important aspects that are relevant to job satisfaction in German horticulture. In addition, the preferences of future generations concerning the job characteristics examined will be considered, with the intention of highlighting the areas to which horticultural companies need to pay particular attention to be attractive employers in the future.

In principle, the satisfaction measurement aims to quantify and evaluate human emotions. To investigate why some people are happier than others, this article includes perspectives that are either "environmentcentered" or "person-centered." In the first case, the influence of the environment on the satisfaction of an individual is considered. The second case investigates the influence that the person's own characteristics have on the individual's experienced satisfaction.

\section{JOB SATISFACTION MEASUREMENT BASED ON THE VITAMIN MODEL}

Research models that help to examine the causes of satisfaction and dissatisfaction show three different points of view: the first is based primarily on the environment, the second is based on the person himself and the third combines the environment and person perspectives. To gain a complete understanding, a model has to be chosen that involves both the environment and the person himself. An emphasis on one or the other point of view does not necessarily deny the need for a combined approach. In principle, there is no single "correct" number of categories in a model of this kind. Increasing accuracy can be achieved by incorporating a higher number of specific characteristics.

The major difference between Warr's vitamin model and other models is not the choice of features, but the idea that the expression of the characteristics does not have a linear relationship with satisfaction. Consequently, there are features that have diminishing marginal utility or that affect satisfaction negatively at very much higher characteristic values (see Fig. 1).

Table 1 lists the 12 features of the vitamin model. The subdivision into sub-features (aspects) is indicated by small letters. The nature of the utility function is given by the abbreviations CE for diminishing marginal utility and AD for a bell-shaped curve (Warr, 2013). In this study, the vitamins are operationalized through the model's 28 aspects.

For all these aspects of the work environment, an increase from a low to a moderate level leads to increasing satisfaction. Research sometimes deals with the "intrinsic" characteristics of the task itself. The vitamin model assumes these intrinsic features to have a bell-shaped profile of the utility function, such that it can lead to "too much of a good thing" (features 1 to 6). On the other hand, the extrinsic characteristics, as a result of the working conditions (features 7 to 12), show diminishing marginal utility above a moderate level.

Job feature 1: The possibility of personal influence (control). Research from many areas of psychology has confirmed the far-reaching importance of personal control over aspects of the environment (Thompson, 2009). This 
work feature depends, like others, on individual cognitive processes and the conditions of the environmental situation. Two aspects of this work feature should be considered, which are of an intrinsic and an extrinsic nature (Karasek, 1979). The intrinsic aspect contains the adaptation of other job characteristics (1a, task discretion), such as the level of skill use, objectives and variety, whereas the extrinsic aspect relates to the influence on the organizational as a whole $(1 \mathrm{~b}$, influence over the wider organization). In the vitamin model, a bell-shaped profile of the utility function is assumed for this work feature: very high values lead to dissatisfaction (Burger, 1989).

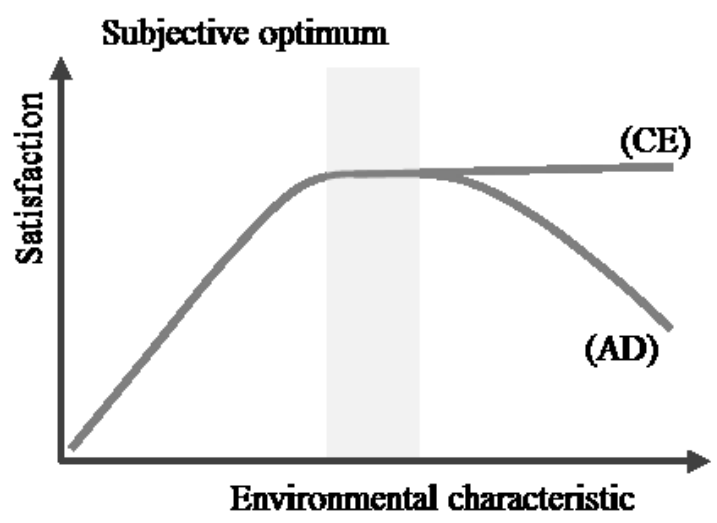

Fig. 1 The vitamin analogy: the bell-shaped curve of the utility function (AD, additional decrement) and diminishing marginal utility (CE, constant effect). Own illustration: Cf. Warr (2012) and Meyerding (2015a).

Job feature 2: The possibility of using skills (skill). There is a variety of evidence that employees who are limited in the use of their skills are less satisfied than others. The personal appreciation of skills (2a, skill use) could be illustrated by the study by Lewin, Dembo, Festinger, and Sears (1944) The opportunity to learn (2b, new learning, Kornhauser, 1962) and to acquire new skills is a key feature in the model of positive progressive work by Spreitzer, Sutcliffe, Dutton, Sonenshein, and Grant (2005). In the vitamin model, a non-linear bellshaped curve of the utility function is assumed for this job feature.

Job feature 3: Externally given goals (goals). Environmental situations differ in the requirements that they place on the physical and mental activity of a person. At low levels of this job feature, few demands are placed on the individual and there is little external pressure to carry out an activity. At moderate levels, the individual is prompted by his or her environment to work towards goals that involve different levels of difficulty.

Very high levels of externally set targets require the individual to achieve many and/or difficult goals, leading to feelings of oppression, the inability to maintain the quantity or quality of work and possibly the fear of failure (Warr, 1987). Work feature 3 has six aspects. The first aspect deals with the number of requests ( $3 \mathrm{a}$, number of job demands) made of the employee. As with other primary features, short periods with low requirements are quite attractive, as they offer rest periods or the possibility to carry out another activity. However, a non-changing situation with low requirements has a negative impact on subjective satisfaction (Wyatt and Langden, 1938). The second aspect is the ability to cope with difficult requirements ( $3 \mathrm{~b}$, difficulty of job demands). Thus, there is an individual optimum of requirements: a certain degree, which also requires effort, is desirable. However, increasing demands lead to excessive demands. The third aspect is task identity ( $3 \mathrm{c}$, task coherence). A specific aspect of goals in a work environment is the degree to which the individual tasks are conclusively related. Hackman and Oldham (1975) defined task identity as the degree to which it is required to fulfil a task "completely," that is, to perform a job from start to finish with a visible result. The fourth aspect is role conflict ( $3 \mathrm{~d}$, conflict between job demands). This is the case in which incompatible demands are made of different environmental sources. Another form of role conflict is described between roles in private life and roles in working life, known as work-home conflict or workfamily conflict (3e, conflict between work and home, Greenhaus and Beutell (1985)). The sixth aspect is $3 f$, emotional dissonance. A special form of high job demands arises in situations in which the employee is expected to show or simulate an emotion without actually feeling it (Glomb, Kammeyer-Mueller and Rotundo, 2004). The vitamin model assumes job feature 3 to have a bell-shaped profile of the utility function. In a nationwide study among British workers, Warr (1990) observed a non-linear relationship.

Job feature 4: Variety (variety). This feature of the vitamin model contains variations $(4 \mathrm{a}$, range of different tasks) in the conditions of the workplace and in the activities that are carried out by the employees. A low variety leads to dissatisfaction for two reasons. First, the absence of variety is undesirable in itself. People prefer a change in their experiences, to find a balance between comfort and relief from repetitive routines and behaviours (Kornhauser, 1962). The bell-shaped curve of the utility function implies that very high variety leads to dissatisfaction. Two reasons for this are feasible. First, very high variety leads to harmful levels of other job characteristics, for example by increasing the number of different external requirements (job feature 3 ). The second negative aspect of high variety lies in the fact that the individual must constantly draw his concentration and attention to other matters.

Job feature 5: Clarity of the environmental situation (clarity). A lack of clarity of the environmental situation is experienced as undesirable in itself. Uncertainty regarding one's own situation leads to anxiety. A low level of predictability reduces the subjective competence in a situation as it is less possible to assess risks and opportunities. Caplan (1975) developed a "job futures ambiguity" scale for the first of the three aspects; this contains the security of career development (5a, future predictability) and the expected future value of one's abilities. 
Table 1. The 12 Vitamins of Warr's Model and its 28 Aspects for the Evaluation

\begin{tabular}{|c|c|c|}
\hline Vitamin model & Job features in the present study & Utility function \\
\hline \multirow[t]{2}{*}{1 Control (AD) } & 1a Task discretion & $\mathrm{AD}$ \\
\hline & $1 \mathrm{~b}$ Influence over the wider organization & $\mathrm{AD}$ \\
\hline \multirow[t]{2}{*}{2 Skill (AD) } & 2a Skill use & $\mathrm{AD}$ \\
\hline & $2 \mathrm{~b}$ New learning & $\mathrm{CE}$ \\
\hline \multirow[t]{6}{*}{3 Goals (AD) } & 3a Number of job demands & $\mathrm{AD}$ \\
\hline & 3b Difficulty of job demands & $\mathrm{AD}$ \\
\hline & $3 \mathrm{c}$ Task coherence & $\mathrm{CE}$ \\
\hline & 3d Conflict between job demands & CE (inverse) \\
\hline & 3e Conflict between work and home & CE (inverse) \\
\hline & 3f Emotional dissonance (inverse) & $\mathrm{AD}$ \\
\hline 4 Variety (AD) & 4a Range of different tasks & $\mathrm{AD}$ \\
\hline \multirow{3}{*}{5 Clarity (AD) } & 5a Future predictability (excludes job tenure) & $\mathrm{AD}$ \\
\hline & $5 \mathrm{~b}$ Clear role requirements & $\mathrm{AD}$ \\
\hline & 5c Availability of feedback & $\mathrm{AD}$ \\
\hline \multirow[t]{2}{*}{6 People (AD) } & 6a Amount of social contact & $\mathrm{AD}$ \\
\hline & 6b Quality of social contact & $\mathrm{AD}$ \\
\hline 7 Money (CE) & 7a Pay level & $\mathrm{CE}$ \\
\hline \multirow[t]{3}{*}{8 Physical security (CE) } & 8a Pleasant environment & $\mathrm{CE}$ \\
\hline & $8 \mathrm{~b}$ Safe work practices & $\mathrm{CE}$ \\
\hline & 8c Adequate equipment & $\mathrm{CE}$ \\
\hline \multirow[t]{2}{*}{9 Significance $(\mathrm{CE})$} & 9a Value to society & $\mathrm{CE}$ \\
\hline & $9 \mathrm{~b}$ Significance to self & $\mathrm{CE}$ \\
\hline \multirow[t]{2}{*}{10 Supervision $(\mathrm{CE})$} & 10a Supervision is considerate & $\mathrm{CE}$ \\
\hline & $10 \mathrm{~b}$ Supervisor is supportive & $\mathrm{CE}$ \\
\hline \multirow[t]{2}{*}{11 Career (CE) } & 11a Job security & $\mathrm{CE}$ \\
\hline & $11 \mathrm{~b}$ Good future prospects & $\mathrm{CE}$ \\
\hline \multirow[t]{2}{*}{12 Fairness (CE) } & 12a Fair treatment of employees & $\mathrm{CE}$ \\
\hline & $12 \mathrm{~b}$ The organization's morality in society & $\mathrm{CE}$ \\
\hline
\end{tabular}

Source: Cf. Warr (2007) and Meyerding (2015a)

The second aspect of clarity of the environmental situation is the clarity of the role ( $5 \mathrm{~b}$, clear role requirements), which contains the amount and availability of information about which conduct and performance levels are required (Glazer and Beehr, 2005).

The third aspect of clarity of the environmental situation is feedback (5c, availability of feedback) about one's own performance, which is essential for an employee to acquire the personal ability to influence or maintain the environmental situation as well as for the development and use of his or her own abilities. There is little information about situations with very high clarity. However, it appears likely that these seriously reduce surprises, risk and different results.

Job feature 6: Contact with other people (people). For job feature 6 , contact with other people, a bell-shaped profile of the utility function is assumed. Two aspects of this feature should be considered: on the one hand the quantity (6a, amount of social contact) and on the other hand the quality (6b, quality of social contact) of contact. The quantity of social contacts and interactions is desirable only up to a certain point (Hackman and Oldham, 1975). A very high value of this aspect prevents privacy and may lead to excessive demands and aggression and thus to dissatisfaction (Fried, Slowik, Ben-David and Tiegs, 2001). Dissatisfaction is due to higher noise levels, more frequent interruptions and distractions from other employees, a sense of overcrowding, insufficient privacy and less friendly conversations due to a lack of discretion (McCoy and Evans, 2005). For all the environmental characteristics, what is a possibility or option at moderate levels is an unavoidable imperative requirement at very high levels. Being forced to seek help may be harmful in this respect (Deelstra et al., 2003).

Job feature 7: Disposable income (money). The availability of financial resources (7a, pay level) has been widely studied in the context of employees' salary. The amount of one's salary is of personal importance, not only to secure a livelihood or a particular lifestyle, but also for social significance, "equal" treatment and as a sign of personal success (Srivastava, Locke and Bartol, 2001). The feature disposable income has a non-linear character. The utility function shows diminishing marginal utility. The relationship between income and satisfaction is higher in low-income groups than at a moderate level (Kornhauser, 1962). At higher income levels, income has only very little or no effect on satisfaction (Sibbald, 2003). Studies in this area have often been based on a version of the equity theory (Adams 1963), which implies that people compare their ratio of input and income with the input-output ratio of other people. The inputs are usually defined in terms of skills, effort, qualifications, working conditions, working hours and so on.

Job feature 8: Physical security (physical security). The central issues of this feature are the absence of danger (8b, safe work practices) and the presence of good working conditions, ergonomically appropriate equipment 
(8c, adequate equipment) and safe levels of, for example, temperature and noise ( $8 \mathrm{a}$, pleasant environment). The aspects of physical security have often been neglected in studies regarding job satisfaction (Taber, Beehr and Walsh, 1985). The key features of physical security were identified by Carlopio (1996) as the environment design (lighting, air quality, surface condition, etc.), machines and tools, sources of danger, sanitation, food and relaxation areas. A low level of physical security will reduce employee satisfaction in three ways. First, there are direct effects, unwanted physical conditions that probably give rise to negative feelings themselves. Second, an indirect effect can occur as a result of an activity-induced deterioration of physical health. Insufficient equipment can be both intrinsically undesirable and the cause of dissatisfaction due to subsequent errors and interruptions in the working process (Salvendy, 2012, p. 708).

Job feature 9: Valued social position (significance). Professions and workplaces differ in the value that is attributed to them by society but also by the organization. The "task significance" scale of the job diagnostic survey (Hackman and Oldham, 1975) includes the importance that employees attach to their work task (9b, significance to self, Hackman and Oldham, 1975). This work feature is more open than others to subjective interpretation. The value that is attached to a particular role may vary widely between individuals in the same role (Wrzesniewski, McCauley, Rozin and Schwartz, 1997). The studies reviewed have consistently demonstrated a linear relationship between appreciation of the role and job satisfaction. At the conceptual level, it remains unlikely that in jobs that all have a high social value, small differences in the expression of this feature may be associated with differences in job satisfaction.

Job feature 10: Supportive leadership (supervision). Issues of leadership were often analysed by surveys that were completed by the staff and recorded their perception of the behaviour of executives in terms of their consideration (10a, supervisor behaves considerately). The questions concerned the support (10b, supervisor is supportive) and the respect shown to the employees, compliance with the welfare of employees and the tendency to express praise and appreciation for the work performed. Behaviour that can be defined as considerate includes willingness to listen and to accept the suggestions of employees. Very high values of the feature supportive supervision will probably not lead to dissatisfaction of subordinates, so a bell-shaped curve of the utility function is not expected.

Job feature 11: Career prospects (career). A career is often understood as upward movement in the work hierarchy. Careers can also develop positively for an individual in other ways, by career changes, taking on an alternative role or engaging in teaching activities. Two aspects of career prospects should be considered. First, jobs differ regarding their job and income security (11a, job security). The second aspect of career prospects is the possibility to take on another role $(11 \mathrm{~b}$, good future prospects). For many people, this means having opportunities for promotion: do I collect experience and expertise on this job, which will be useful to be able to take a position with a higher status, and/or will such a position be available to me in the future? However, this outlook includes the opportunity for transition to other activities, which need not imply a hierarchical ascent. Diminishing marginal utility is assumed for this job feature.

Job feature 12: Equality (fairness). The last job feature with diminishing marginal utility in the vitamin model contains two aspects of equality: the fairness in the relationship of an employee and his employer (12a, fair treatment of employees) and the fairness of the company towards the society as a whole $(12 \mathrm{~b}$, the organization's morality in society). Organizational justice of the first kind (within the organization) contains distribution-related and procedural issues. Distributive justice refers to the fairness or, in other words, the allocation of workload and benefits to the different members of a social system. Procedural justice refers to the fairness of the process that leads to this allocation (Cropanzano, Bowen and Gilliland, 2007), particularly concerning direct unfair discrimination on the basis of age, gender, ethnic origin and so on. Above a moderate level, the utility function should flatten out (Warr, 2007, p. 140).

To evaluate the characteristics, a modified Kunin (1955) scale was used to make it easier for the respondents to grasp the nature of the characteristic values. This is particularly necessary, as linearity is often assumed by study participants. The symbols used are derived from a publication by Salcher and Hoffelt (1995, p. 95). In addition to this questionnaire, the individual preferences for certain characteristics should be recorded. Furthermore, it can be useful to capture some personal data.

\section{Personal Characteristics and their Influence on} Subjective Satisfaction

Environmental features are responsible for only part of satisfaction. Part of satisfaction comes from the person him- or herself or his or her characteristics or properties. Knowledge of the influence of personal characteristics is important to be able to interpret the results of measurement correctly.

\section{Different individual comparison processes and reference values}

If an employee is asked to evaluate a particular job feature, he/she turns to comparisons and looks for reference values with which to compare his/her individual situation. Depending on which reference values are used, the subjective evaluation and therefore the satisfaction change, regardless of the objective characteristic value. The individual evaluation processes, especially for moderate objective characteristic values, can be expected to contribute to the determination of subjective satisfaction, but their influence should be low for extreme objective characteristic values (Frese and Zapf, 1999).

Demographic characteristics and their influence on subjective satisfaction. Overall, women tend to have higher job satisfaction than men (Grandey, Cordeiro and Crouter, 2005). However, whether a causal relationship between gender and satisfaction can be derived is 
questionable. Nevertheless, with regard to the job features, differences between the genders can be observed (Grandey, Cordeiro and Crouter, 2005). It has frequently been noted that older people are more satisfied than younger people (Diener and Suh, 1998). The reasons for the greater satisfaction of older people could lie in changed evaluation processes or in different characteristic values of the job features. In the first case, older people could, through their work and life experience, have lowered their expectations towards the job, while younger workers have positive expectations regarding their working life, which are then disappointed and lead to dissatisfaction. The second possible explanation could be that older employees tend to occupy jobs with a higher job quality (more positive levels of job features) or may, during their working lives, develop in a direction that is conducive to their needs.

Different forms of employment and their influence on subjective satisfaction. The third kind of group distribution could occur in relation to different forms of employment with different characteristics, for example part-time and full-time jobs or fixed and temporary employment (Thorsteinson, 2003). It is also useful to distinguish between core workers and seasonal workers, as seasonal workers occupy a special position in German horticulture.

Influence of the individual personality on subjective satisfaction. Other personal characteristics that have an impact on subjective satisfaction are personality and innate cognitive differences. Psychological research typically distinguishes between five personality characteristics: (Barrick and Mount, 1991) neuroticism, extraversion, openness to new experiences, agreeableness (cooperation, respecting the wishes of others, etc.) and conscientiousness (diligence). The personality characteristics will not be discussed in detail at this point; however, it is crucial to be aware that sometimes innate characteristics may influence perceived subjective satisfaction. They are not considered in this study. In addition, one's own abilities and level of education could affect one's subjective satisfaction (Ganzach, 1998). However, a higher level of education increases the probability of acquiring a job that has beneficial levels of different job characteristics.

\section{DATA AND METHODS}

For the study, more than 1,300 employees, vocational and master craftsman scholars as well as horticulture students in Germany were surveyed. The questionnaire was implemented in both paper-and-pencil form and webbased form. Individuals were invited to participate via presentations, trade fairs (IPM), lectures and social networks as well as two articles in the horticultural trade press (TASPO). The survey was conducted from August 2013 to February 2015. Over 200 completed questionnaires from employees of horticultural companies were analysed. In this article, the groups of vocational and master craftsman scholars as well as horticulture students in Germany are considered, each of which accounted for over 200 completed questionnaires, so a total of 600 completed questionnaires were evaluable. Only questionnaires with more than 10 completed questions were included in the analysis.

First, the sample is described for each group, and then the relationships between job aspects and job and life satisfaction are investigated. For this purpose, the rank correlation coefficient Spearman's rho $\left(r_{s}\right)$ is used, since normal distribution cannot be assumed (Field 2009, pp. 179 ff.). For each correlation coefficient, the significance level $(p)$ and the number of records $(n)$ used in the calculation are indicated.

The model was tested in different ways. Covariance structure modelling (CSM) with full-information maximum likelihood (FIML) estimation was used to assess the fit of the proposed vitamin model and its operationalization in this study (Meyerding, 2015a). Also dummy variables were calculated for the aspects for which the utility function should have a bell-shaped curve. For each of these aspects, two dummy variables were constructed. The first includes the records of low to moderate characteristic values and the second those of moderate to very high scores. In the case of a bell-shaped curve of the utility function (AD), the first dummy variable should have a positive correlation with job satisfaction (see Fig. 1, left side) and the second a negative correlation (see Fig. 1, right side). In addition, the attributes for which a bell-shaped curve of the utility function is assumed are transformed into a third dummy variables so that characteristic values over the subjective optimum are assigned to the values on the left side of the optimum. The correlation between thus transformed dummy variables and job satisfaction should be higher than those of the variable without the transformation, provided that this aspect has a bell-shaped profile of the utility function (AD). A further possibility, which is to be investigated, is the comparison of the results of a linear regression for each aspect and a non-linear regression, wherein the non-linear regression should present a higher $R^{2}$ than the linear regression if the assumed utility functions can be supported by the data. In the case of the non-linear regression, the following equations are used: Concave with saturation limit (exponential model, CE characteristics (aspects)) (Eq.1).

Job satisfaction $=M-a \cdot e^{(-b \cdot x)}$

where $\mathrm{x}$ is the value of the job characteristic and the start values were chosen as follows):

$\mathrm{a}=1 ; \mathrm{b}=0.5 ; \mathrm{M}=10$

Concave with downturn (quadratic model, AD characteristics (aspects)) (Eq.2).

Job satisfaction $=a+b \cdot x-c \cdot x^{2}$

where $\mathrm{x}$ is the value of the job characteristic and the start values were chosen as follows:

$\mathrm{a}=5.6 ; \mathrm{b}=5.3 ; \mathrm{c}=10$

As explained above, not only environmental characteristics, but also personal characteristics have an impact on subjective satisfaction (Warr, 2013). 
Therefore, they should be considered in the study. These are specifically gender, age and level of education. Furthermore, the type of employment, the size of the company and their influence on the subjective satisfaction of workers in German horticulture are considered.

\section{RESULTS AND DISCUSSION}

\section{Results of the Satisfaction and Preference Measurement of Vocational and Master Craftsman Scholars in German Horticulture}

\section{Sample Description}

Over 200 people participated in the study between August 2014 and December 2014 in the group of vocational and master craftsman scholars. In contrast to the group of employees, the vocational and master craftsman scholars were surveyed exclusively with questionnaires in paper form. The questionnaires were distributed by teachers in their classes. The group of vocational and master craftsman scholars is evaluated separately from the employees of horticultural companies, since the two groups differ particularly by age and life reality. The majority of the study participants in this group come from the states of Bavaria and Baden Württemberg and work in service horticulture and floriculture, followed by multidivisional companies, tree nurseries and vegetable farms. Trade firms, pomiculture and retail horticulture are virtually absent. The divisions in the study are therefore not representative of the population (Gurrath, 2006). The average age of the vocational and master craftsman scholars who participated in the study is 24 years and shows an accumulation between 17 and 25 years.

As might be expected, the majority of the sample is undertaking an apprenticeship (39\%) or has already completed an apprenticeship (49\%). In individual cases, however, a specialist degree $(9 \%)$ or even a university of applied sciences $(2 \%)$ or university degree $(2 \%, N=174)$ already exists. Most of the respondents work in horticultural companies that employ between 6 and 10 employees (excluding seasonal workers, $33 \%, N=196$ ) and up to 5 seasonal workers $(80 \%, N=196)$. More than half of the vocational and master craftsman scholar respondents are male $(67 \%, N=200)$ and are not selfemployed $(92 \%, N=198)$. A total of $97 \%$ of the study participants are employed full-time; $98 \%$ belong to the core workforce of the company $(N=153)$ and $54 \%$ do not have any form of management responsibilities $(N=188)$.

Preferences of Vocational and Master Craftsman Scholars Concerning the Job Characteristics Examined The vocational and master craftsman scholars were asked about their preferences regarding the job aspects investigated. For this purpose, they were required to imagine their dream job and specify the importance of each feature on a 6-point Likert scale. Fig. 2 shows the average values for the 28 aspects explored $(N=\varnothing 205$, standard deviation between 1.0 and 1.2).

The fair treatment of employees (no discrimination) comes first $(5.21,12 \mathrm{a})$, followed by the possibility of being oneself at work (emotional dissonance; 5.11, 3f).
The possibility to expand one's abilities and to learn (5.07, $2 b)$ is also strongly preferred by the vocational and master craftsman scholars. In the fourth place, we find the work aspect suitable equipment (including machines, 4.98, 8c), and the balance between work and family life ranks fifth $(4.91,3 \mathrm{e})$. Job aspects such as the level of salary $(4.44,7 \mathrm{a})$ and the overall behaviour of the company (towards suppliers, customers, the environment, etc., 4.43, 12b) find themselves in the middle, occupying the thirteenth and fourteenth ranks. Least important appears to be the level of task difficulty $(3.66,3 \mathrm{~b})$ and the possibility to have an impact on the organization as a whole (e.g. by trade unions or work councils, $3.44,1$ b).

\section{Covariance Structure Modelling}

Covariance structure modelling (CSM) with fullinformation maximum likelihood estimation was used to assess the model fit of the vitamin model and the aspects in the present study.

CSM is a multivariate instrument which combines methodological and statistical contributions from psychometric as well as econometric theory (Diamantopoulos, 1994; Meyerding, 2015a). CSM represents an integration of two models (Backhaus, Weiber and Erichson, 2013, pp. 63-118): (1.) the measurement or confirmatory factor analytic model, which examines the contributions of the performed measures (aspects) to the hypothetical latent vitamins, and (2.) the structural equation model, which defines (causal) relationships among these latent factors (the vitamins and job satisfaction). The corresponding analyses were performed using IBM SPSS AMOS (Meyerding, 2015a). Missing observations were handled by leastwise deletion. Fig. 3 shows the path diagram of the performed structural equation model. The intercorrelations between the vitamins are not shown in this diagram for reasons of readability; they can be seen in Table 2 . The vitamins 1 through 12 (in the text also referred to as job feature 1-12) are latent variables which are operationalized by the 28 aspects in the present study (Meyerding, 2015a).

The factor loadings (printed on the arrows from the vitamins to the aspects in Fig. 3) indicate the contribution of each aspect to the factor (vitamin). As the factor loadings are mostly above .63 they can be seen strong (Comrey and Lee, 2013, p. 243). The hypothetical vitamins are then associated with job satisfaction. In this model the transformed variables for the additional decrement (AD) features were used (Meyerding, 2015a). In other words, nonlinearity is not tested. The model is recursive $(N=205)$, it is identifiable with degrees of freedom of 302. The assessment of normality reported acceptable values of kurtosis $|<2|$ and skewness $|<7|$ (Weiber and Mühlhaus, 2014) for the vitamin model (Fig. 3).

Normality distribution cannot be reported in the case of a personal characteristics model (Fig. 4 and Table 3, $N=205$, $d f=0)$ as core employee status (skew $=6.95$, kurtosis $=46.27$ ) and part time status (skew $=-5.59$, kurtosis $=29.20$ ) show no acceptable values. 


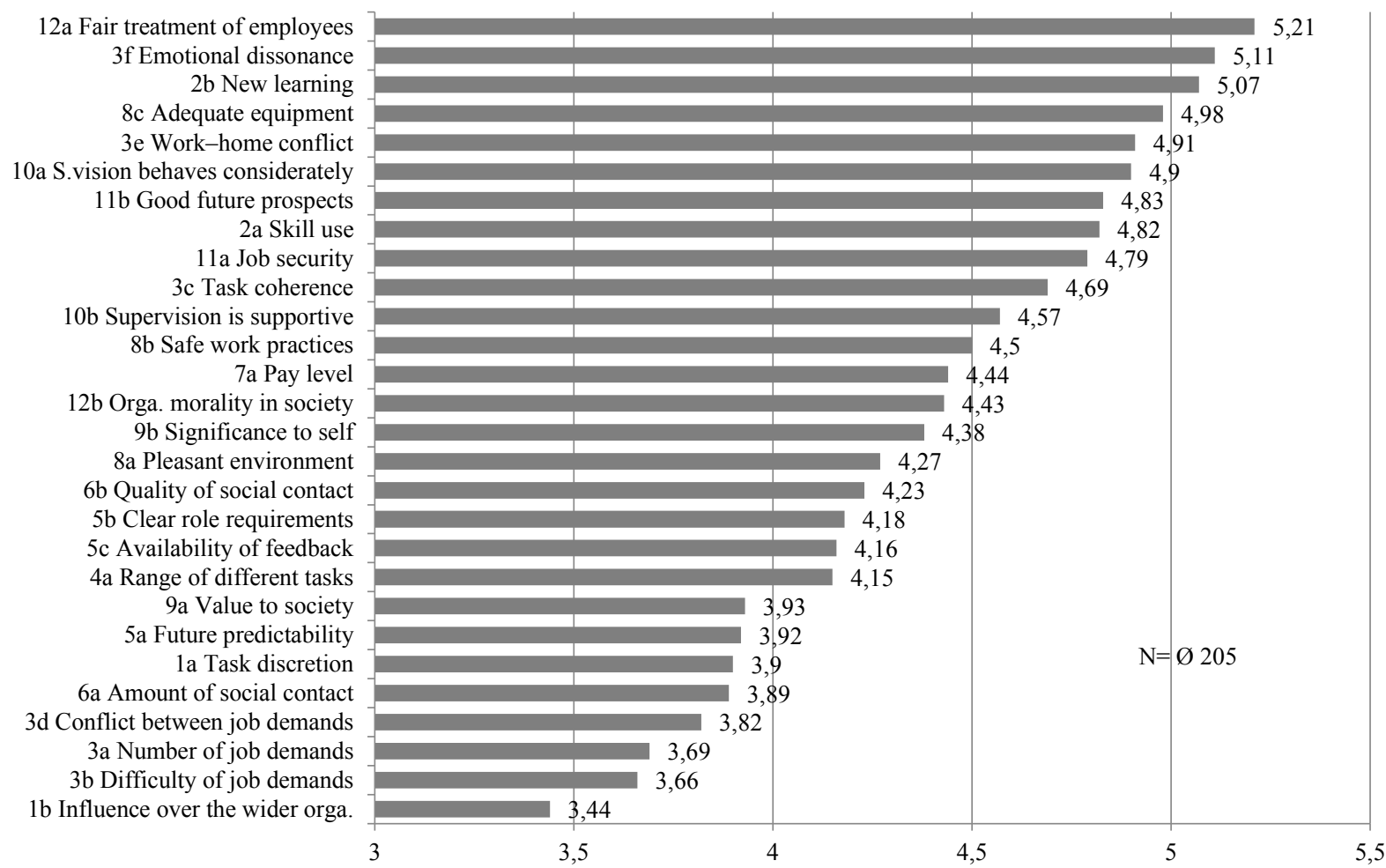

Fig 2 Preferences regarding job characteristics (vocational and master craftsman scholars).

As this is essential to perform maximum likelihood estimation (Meyerding, 2015a), the vitamins and the personal characteristics are not analysed in one CSM, because of this reason. Furthermore the personal characteristics model (Fig. 4) should be considered with caution.

The factor loadings of all aspects of the vitamins are significant as the critical ratios (CR) are all above 1.96 (Backhaus, Erichson and Weiber, 2013, p.141). Chisquare (CMIN) equals 716.41 for the default vitamin model (Fig. 3) divided by the degrees of freedom $(d f=302)$ equals $2.37(\mathrm{CMIN} / d f)$, which represents a appropriate model fit for the whole structural equation model (Backhaus, Erichson and Weiber, 2013, p. 147; Meyerding 2015a). This is again not the case for the personal characteristics model (Fig. 4, $\mathrm{CMIN}=0, d f=0$, $\mathrm{CMIN} / d f=$ N.A.). Because chi-square is problematic especially for complex models (Reinecke, 2005, pp. 116 ff.), the root-mean-square-error of approximation (RMSEA) was calculated, which measures how well the model fits to the "reality" of the empirical data. A value of about .08 or less for the RMSEA would indicate a reasonable error of approximation, a value of .10 and above represents an insufficient model fit (Browne and Cudeck 1992; Meyerding, 2015a). The RMSEA of the default vitamin model is .08 (personal characteristics model RMSEA=.15).

\section{Influence of the Investigated Aspects on Job and Life Satisfaction}

Table 4 shows the Spearman correlation coefficient (rho) for all 28 job aspects and job and life satisfaction. For the $\mathrm{AD}$ aspects with an assumed bell-shaped curve of the utility function (see Fig. 1), the transformed dummy variables were used. In the first column $(\mathrm{J})$, the correlation coefficients as a measure of the strength of the relationship between individual job aspects and job satisfaction are listed. In the second column (L), they are shown for life satisfaction.

The job aspect $3 \mathrm{f}$, emotional dissonance, shows the strongest relation with job satisfaction among the respondents. In the second and third places are the job aspects 10a, supervisor behaves considerately, and 10b, supportive supervision, followed by $12 \mathrm{a}$, fair treatment of employees, and in fifth place is $12 \mathrm{~b}$, the organization's morality towards society. In addition, the job aspects $9 b$, the value of work for oneself, and $11 \mathrm{~b}$, good future prospects, are strongly related to job satisfaction. In the midfield, aspects like $2 b$, learning, $3 c$, task integrity, 2a, skills use, 3e, conflict between work and family life, and 7a, salary level, come into place. The last places are occupied by $1 \mathrm{a}$, job autonomy, $3 \mathrm{~b}$, difficulty level of the tasks, and $4 \mathrm{a}$, variety. No significant correlation in the sample could be observed between the number of social contacts (6a) and job satisfaction.

As in other studies, the relationships between subjective characteristic values and context-free life satisfaction are less strong than with contextual job satisfaction (Rice, Frone and McFarlin, 1992). The strongest connection with life satisfaction for vocational and master craftsman scholars is shown by the job characteristic $9 b$, value of work for oneself. In second place, $12 \mathrm{~b}$, fair treatment of the society as a whole (suppliers, customers, the environment, etc.) can be found, followed by $3 \mathrm{f}$, emotional dissonance (to be completely oneself at work), 9a, the value of the work for society, and 
10a, considerate leadership. Salary, for example, shows only a weak connection with life satisfaction. Of the 28 job aspects, 9 show no significant relationship with context-free subjective life satisfaction.

Non-Linearity of the Utility Functions of the Job Aspects For the group vocational and master craftsman scholars, the non-linearity of the utility functions of the 28 job aspects were also examined. Here, three approaches were used to verify the functions; the results are compared in Table 5. The first column shows the Spearman correlation coefficient for a linear model (without transformation). The second column shows the transformed job aspect dummy variables for which a bell-shaped curve of the utility function is assumed.
Columns three and four provide the correlation coefficients for the dummy variables of the second approach, in which the effective directions for the low and high characteristic values are compared. The last and second-last columns of Table 5 show the results of the linear and non-linear regressions (coefficient of determination $R^{2}$ ) for the third comparative approach. The regression equations, which are the bases for the nonlinear regressions, reflect the assumed curves of the utility functions (CE aspects = exponential function; $\mathrm{AD}$ aspects $=$ quadratic function as shown in Fig. 1 and the explanations given in the methods section).

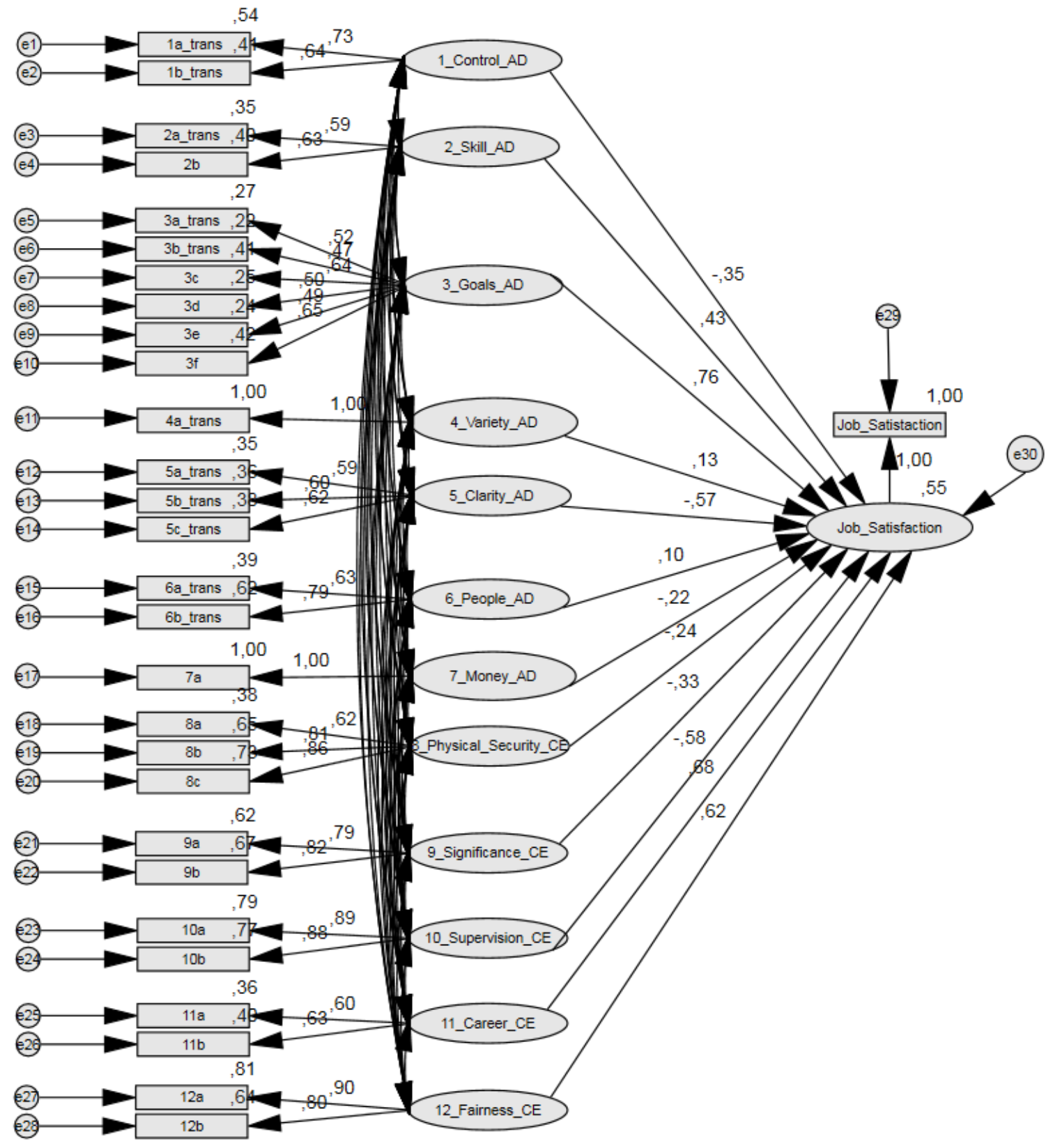

Fig 3 Path diagram of the covariance structure modelling (standardized estimates) for the vitamin model. The intercorrelations between the vitamins are not shown in this diagram for reasons of readability. Source: Authors' estimations. 
Table 2. Correlation Matrix for the 12 Estimated Vitamins

\begin{tabular}{|c|c|c|c|c|c|c|c|c|c|c|c|}
\hline \multirow{2}{*}{1 Control (AD) } & 1 & 2 & 3 & 4 & 5 & 6 & 7 & 8 & 9 & 10 & 11 \\
\hline & & & & & & & & & & & \\
\hline 2 Skill (AD) & .78 & & & & & & & & & & \\
\hline 3 Goals (AD) & .64 & 1.12 & & & & & & & & & \\
\hline 4 Variety $(\mathrm{AD})$ & .48 & .48 & .43 & & & & & & & & \\
\hline 5 Clarity (AD) & .61 & .92 & .74 & .49 & & & & & & & \\
\hline 6 People (AD) & .48 & .58 & .59 & .44 & .71 & & & & & & \\
\hline 7 Money (CE) & .16 & .44 & .45 & .13 & .22 & .19 & & & & & \\
\hline 8 Physical security (CE) & .14 & .67 & .61 & .26 & .51 & .25 & .51 & & & & \\
\hline 9 Significance $(\mathrm{CE})$ & .15 & .72 & .60 & .33 & .53 & .29 & .43 & .58 & & & \\
\hline 10 Supervision (CE) & .32 & .78 & .75 & .25 & .61 & .40 & .31 & .65 & .57 & & \\
\hline 11 Career $(\mathrm{CE})$ & .37 & .88 & .70 & .25 & .75 & .44 & .60 & .70 & .73 & .79 & \\
\hline 12 Fairness (CE) & .27 & .69 & .62 & .23 & .63 & .31 & .33 & .62 & .62 & .81 & .71 \\
\hline
\end{tabular}

Source: Authors' estimations.

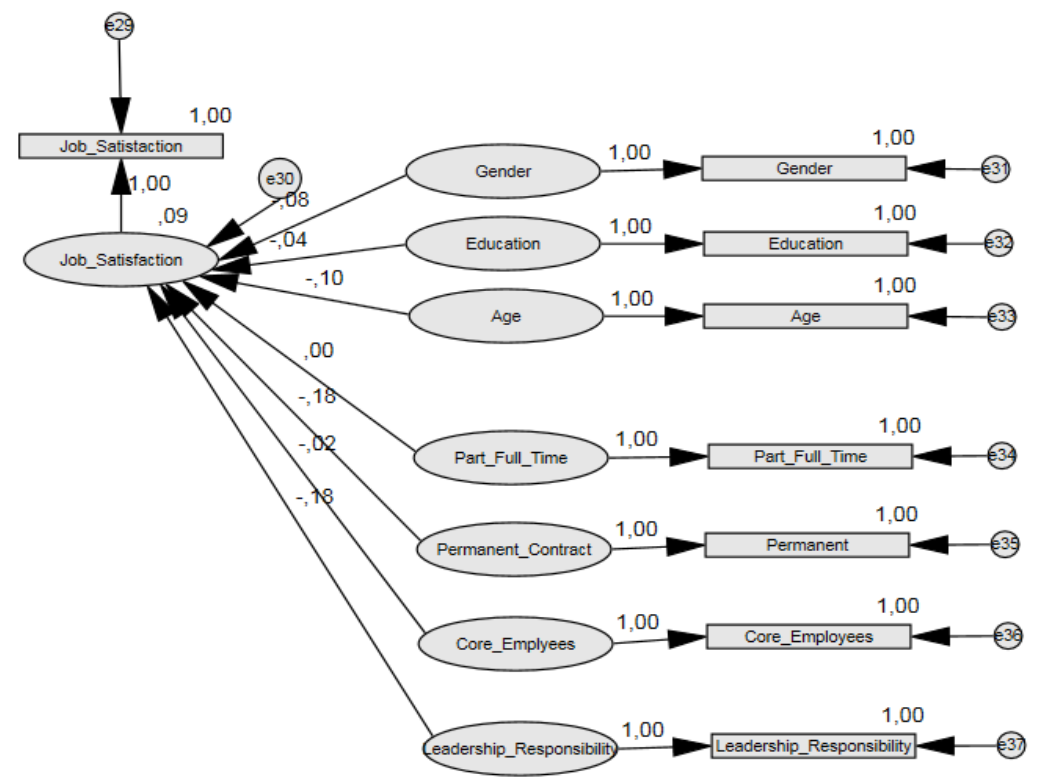

Fig 4 Path diagram of the covariance structure modelling (standardized estimates) for the personal characteristics model. Source: Authors' estimations.

Table 3. Correlation Matrix for the 7 Estimated Personal Characteristics

\begin{tabular}{lrrrrrr}
\hline & 1 & 2 & 3 & 4 & 5 & 6 \\
\hline 1 Gender & & & & & & \\
2 Education & .28 & & & & & \\
3 Age & .19 & .34 & & & & \\
4 Part_Full_Time & .06 & -.05 & -.12 & & & \\
5 Permanent_Contract & -.20 & -.28 & -.06 & -.04 & & \\
6 Core_Employees & .03 & .00 & .09 & .02 & -.04 & \\
7 Leadership_Respons. & -.32 & -.22 & -.15 & .01 & .43 & -.01 \\
\hline
\end{tabular}

Source: Authors' estimations.

As shown in columns one and two of Table 5, the observed relationships of the transformed dummy variables are in all cases far beyond those of the variables without transformation (column one). In addition, the second approach to testing the vitamin model (Warr, 2007) supports the idea of non-linear relationships. The dummy variables in column three of the low characteristic values of the $\mathrm{AD}$ aspects show positive correlations with job satisfaction. Furthermore, the dummy variables in column four show relationships that support Warr's assumptions (Warr, 1987; 1994), as these variables with the characteristic values above the subjective optimum (see Fig. 1) are negatively correlated with job satisfaction.
The $\mathrm{AD}$ aspects $1 \mathrm{a}$, job autonomy, and $1 \mathrm{~b}$, influence over the organization, are exceptions. This can be explained by the fact that very high characteristic values of these job aspects rarely occur in the sample. In all cases, the nonlinear regression shows a higher $R^{2}$ than the linear regression. The underlined regression equations for nonlinear regressions explain job satisfaction better than a linear model. The entire model with 28 investigated job aspects, using the transformed dummy variables in the case of $\mathrm{AD}$ aspects, shows a high $R^{2}$ of .51 in the linear regression for the group of vocational and master craftsman scholars. The examined aspects of work therefore explain $51 \%$ of job satisfaction in the sample. 
Table 4. Relationships between Job Aspects and Work and Life Satisfaction $(N=\varnothing 200)$

\begin{tabular}{|c|c|c|c|c|c|c|c|c|c|c|c|c|c|c|c|c|c|c|c|c|c|c|c|c|c|c|c|c|c|}
\hline & $\mathrm{J}$ & $\mathrm{L}$ & $2 b$ & $3 \mathrm{c}$ & $3 \mathrm{f}$ & $7 \mathrm{a}$ & $8 \mathrm{a}$ & $8 \mathrm{~b}$ & $8 \mathrm{c}$ & $9 \mathrm{a}$ & $9 \mathrm{~b}$ & 10a & $10 \mathrm{~b}$ & 11a & $11 \mathrm{~b}$ & $12 \mathrm{a}$ & $12 \mathrm{~b}$ & $3 \mathrm{~d}$ & $3 \mathrm{e}$ & 1a & $1 \mathrm{~b}$ & $2 \mathrm{a}$ & $3 a$ & $3 \mathrm{~b}$ & $4 \mathrm{a}$ & $5 \mathrm{a}$ & $5 \mathrm{~b}$ & $5 \mathrm{c}$ & $6 a$ \\
\hline J Job satisfaction & 1 & & & & & & & & & & & & & & & & & & & & & & & & & & & & \\
\hline L Life satisfaction & $.65^{* *}$ & 1 & & & & & & & & & & & & & & & & & & & & & & & & & & & \\
\hline $2 \mathrm{~b}$ New learning & $.40^{* *}$ & $.25 * *$ & 1 & & & & & & & & & & & & & & & & & & & & & & & & & & \\
\hline 3c Task coherence & $.37 * *$ & $.25 * *$ & $.62 * *$ & 1 & & & & & & & & & & & & & & & & & & & & & & & & & \\
\hline 3f Emotional dissonance & $.52 * *$ & $.38 * *$ & $.47 * *$ & $.46^{* *}$ & 1 & & & & & & & & & & & & & & & & & & & & & & & & \\
\hline 7a Pay level & $.33 * *$ & $.17^{*}$ & $.38^{* *}$ & $.27^{* *}$ & $.34 * *$ & 1 & & & & & & & & & & & & & & & & & & & & & & & \\
\hline 8a Pleasant environment & $.21 * *$ & $.20 * *$ & $.28 * *$ & $.19^{* *}$ & $.27^{* *}$ & $.37 * *$ & 1 & & & & & & & & & & & & & & & & & & & & & & \\
\hline 8b Safe work practices & $.26^{* *}$ & $.15^{*}$ & $.37^{* *}$ & $.35^{* *}$ & $.32 * *$ & $.43^{* *}$ & $.53^{* *}$ & 1 & & & & & & & & & & & & & & & & & & & & & \\
\hline $8 \mathrm{c}$ Adequate equipment & $.30^{* *}$ & $.25 * *$ & $.42 * *$ & $.26^{* *}$ & $.37 * *$ & $.42 * *$ & $.51 * *$ & $.69 * *$ & 1 & & & & & & & & & & & & & & & & & & & & \\
\hline 9a Value to society & $.31 * *$ & $.37 * *$ & $.34 * *$ & $.21 * *$ & $.28^{* *}$ & $.41 * *$ & $.37 * *$ & $.41^{* *}$ & $.46^{* *}$ & 1 & & & & & & & & & & & & & & & & & & & \\
\hline 9b Significance to self & $.44 * *$ & $.44 * *$ & $.43 * *$ & $.38^{* *}$ & $.46^{* *}$ & $.29 * *$ & $.26^{* *}$ & $.31^{* *}$ & $.41^{* *}$ & $.62^{* *}$ & 1 & & & & & & & & & & & & & & & & & & \\
\hline $\begin{array}{l}\text { 10a Considerate } \\
\text { Supervision }\end{array}$ & $.50^{* *}$ & $.34 * *$ & $.51 * *$ & $.44^{* *}$ & $.41^{* *}$ & $.30^{* *}$ & $.35 * *$ & $.50^{* *}$ & $.47^{* *}$ & $.40^{* *}$ & $.47 * *$ & 1 & & & & & & & & & & & & & & & & & \\
\hline $\begin{array}{l}10 \mathrm{~b} \text { Supervision is } \\
\text { supportive }\end{array}$ & $.49^{* *}$ & $.30^{* *}$ & $.52^{* *}$ & $.40^{* *}$ & $.40^{* *}$ & $.35^{* *}$ & $.31 * *$ & $.45^{* *}$ & $.43^{* *}$ & $.36^{* *}$ & $.50^{* *}$ & $.76^{* *}$ & 1 & & & & & & & & & & & & & & & & \\
\hline 11a Job security & $.25^{* *}$ & $.25 * *$ & $.37 * *$ & $.25^{* *}$ & $.20^{* *}$ & $.35 * *$ & $.22 * *$ & $.44 * *$ & $.49^{* *}$ & $.35^{* *}$ & $.37 * *$ & $.45^{* *}$ & $.43^{* *}$ & 1 & & & & & & & & & & & & & & & \\
\hline $11 \mathrm{~b}$ Good future prospects & $.41 * *$ & $.31 * *$ & $.43 * *$ & $.34 * *$ & $.40^{* *}$ & $.40 * *$ & .11 & $.26^{* *}$ & $.36^{* *}$ & $.37 * *$ & $.39 * *$ & $.39 * *$ & $.41^{* *}$ & $.39 * *$ & 1 & & & & & & & & & & & & & & \\
\hline $\begin{array}{l}\text { 12a Fair treatment } \\
\text { of employees }\end{array}$ & $.48 * *$ & $.33 * *$ & $.43^{* *}$ & $.30^{* *}$ & $.42^{* *}$ & $.32 * *$ & $.34 * *$ & $.37^{* *}$ & $.46^{* *}$ & $.43^{* *}$ & $.46^{* *}$ & $.66^{* * *}$ & $.65^{* *}$ & $.38^{* *}$ & $.44 * *$ & 1 & & & & & & & & & & & & & \\
\hline $\begin{array}{l}\text { 12b Orga. morality } \\
\text { in society }\end{array}$ & $.45^{* *}$ & $.39 * *$ & $.37^{* *}$ & $.29^{* *}$ & $.39 * *$ & $.28 * *$ & $.46 * *$ & $.39 * *$ & $.49^{* *}$ & $.44^{* *}$ & $.44 * *$ & $.53^{* *}$ & $.52^{* *}$ & $.37^{* *}$ & $.36^{* *}$ & $.70^{* *}$ & 1 & & & & & & & & & & & & \\
\hline 3d Conflict job demands & $.30^{* *}$ & $.18^{*}$ & $.39 * *$ & $.38^{* *}$ & $.42^{* *}$ & $.28 * *$ & $.29 * *$ & $.40^{* *}$ & $.41^{* * *}$ & $.27 * *$ & $.35^{* *}$ & $.41^{* *}$ & $.37 * *$ & $.37^{* *}$ & $.25^{* *}$ & $.39 * *$ & $.41^{* *}$ & 1 & & & & & & & & & & & \\
\hline 3e Work-home conflict & $.35^{* *}$ & $.20 * *$ & $.27 * *$ & $.24 * *$ & $.34 * *$ & $.29 * *$ & $.31 * *$ & $.35^{* *}$ & $.35^{* *}$ & $.25^{* *}$ & $.27 * *$ & $.44 * *$ & $.38^{* *}$ & $.22 * *$ & .13 & $.35^{* *}$ & $.32 * *$ & $.46^{* *}$ & 1 & & & & & & & & & & \\
\hline 1a Task discretion & $.20^{* *}$ & .01 & $.27^{* *}$ & $.29 * *$ & $.21 * *$ & .06 & .07 & .11 & .11 & .00 & .11 & $.17^{*}$ & $.27^{* *}$ & .10 & $.19^{* *}$ & $.18^{*}$ & .07 & $.16^{*}$ & .10 & 1 & & & & & & & & & \\
\hline $\begin{array}{l}1 \mathrm{~b} \text { Influence over the } \\
\text { wider orga. }\end{array}$ & $.24 * *$ & 0,09 & $.29^{* *}$ & $.26^{* *}$ & $.24 * *$ & $.25 * *$ & .04 & $.17^{*}$ & .11 & .13 & $.14^{*}$ & $.16^{*}$ & $.21^{* *}$ & .13 & $.27 * *$ & $.22 * *$ & $.18^{*}$ & $.24 * *$ & .10 & $.43^{* *}$ & 1 & & & & & & & & \\
\hline 2a Skill use & $.35^{* *}$ & $.17^{*}$ & $.32 * *$ & $.35^{* *}$ & $.31 * *$ & .14 & .09 & $.27^{* *}$ & $.26^{* *}$ & $.18^{* *}$ & $.29 * *$ & $.30^{* *}$ & $.34^{* *}$ & $.14 *$ & $.22 * *$ & $.29 * *$ & $.23^{* *}$ & $.27^{* *}$ & $.27^{* *}$ & $.40^{* *}$ & $.31^{* *}$ & 1 & & & & & & & \\
\hline $\begin{array}{l}\text { 3a Number of } \\
\text { job demands }\end{array}$ & $.27^{* *}$ & $.16^{*}$ & $.19^{* *}$ & .13 & $.18^{*}$ & $.16^{*}$ & .11 & $.15^{*}$ & .12 & .10 & .13 & $.19^{* *}$ & $.28^{* *}$ & .03 & .02 & $.17^{*}$ & .12 & $.22^{* * *}$ & $.20^{* *}$ & $.28 * *$ & $.20 * *$ & $.22 * *$ & 1 & & & & & & \\
\hline $\begin{array}{l}\text { 3b Difficulty of } \\
\text { job demands }\end{array}$ & $.18^{*}$ & .02 & $.28^{* *}$ & $.24^{* *}$ & $.15^{*}$ & .08 & .04 & .08 & .12 & .01 & $.15^{*}$ & $.18^{*}$ & $.22^{* *}$ & .10 & .12 & .09 & .13 & .11 & .05 & $.35^{* *}$ & $.20 * *$ & $.31^{* *}$ & $.43 * *$ & 1 & & & & & \\
\hline $\begin{array}{l}\text { 4a Range of different } \\
\text { tasks }\end{array}$ & $.15^{*}$ & .10 & .08 & .02 & $.15^{*}$ & .07 & $.21^{* *}$ & 0,14 & $.14^{*}$ & $.21^{* *}$ & $.15^{*}$ & $.18^{*}$ & $.17^{*}$ & -.05 & $.15^{*}$ & $.16^{*}$ & .12 & .11 & .10 & $.26^{* *}$ & $.27^{* *}$ & $.32^{* *}$ & $.40^{* *}$ & $.38^{* *}$ & 1 & & & & \\
\hline 5a Future predictability & $.25 * *$ & .10 & $.25^{* *}$ & $.15^{*}$ & $.15^{*}$ & .13 & .03 & $.14 *$ & $.24^{* *}$ & $.20^{* *}$ & $.18^{* *}$ & $.23 * *$ & $.31^{* *}$ & $.14 *$ & $.40^{* *}$ & $.28 * *$ & $.19^{* *}$ & $.20 * *$ & $.17^{*}$ & $.26^{* *}$ & $.30^{* *}$ & $.30 * *$ & .14 & $.22 * *$ & $.20^{* *}$ & 1 & & & \\
\hline $5 \mathrm{~b}$ Clear role requirements & $.31^{* *}$ & .13 & $.28^{* *}$ & $.24 * *$ & $.27 * *$ & .09 & $.22 * *$ & $.22^{* *}$ & $.26^{* *}$ & $.17^{*}$ & $.27 * *$ & $.22^{* *}$ & $.24 * *$ & $.20^{* *}$ & $.26^{* *}$ & $.26^{* *}$ & $.29 * *$ & $.25 * *$ & $.24 * *$ & $.32 * *$ & $.28^{* *}$ & $.36 * *$ & $.24 * *$ & $.29 * *$ & $.26 * *$ & $.37^{* *}$ & 1 & & \\
\hline 5c Availability of feedback & $.26 * *$ & .03 & $.30^{* *}$ & $.21 * *$ & $.29 * *$ & .11 & .08 & $.27 * *$ & $.24 * *$ & $.21^{* *}$ & $.32^{* *}$ & $.38 * *$ & $.42 * *$ & $.21^{* *}$ & $.21^{* *}$ & $.36^{* *}$ & $.34 * *$ & $.36 * *$ & $.25^{* *}$ & $.22 * *$ & $.18^{*}$ & $.34 * *$ & $.24 * *$ & $.17^{*}$ & $.23^{* *}$ & $.32 * *$ & $.34 * *$ & 1 & \\
\hline 6a Amount of social contact & .12 & .07 & .10 & .07 & .14 & .12 & $.19^{* *}$ & .10 & .08 & $.14^{*}$ & $.25^{* *}$ & $.18^{*}$ & $.23 * *$ & -.00 & $.19^{* *}$ & $.20^{* *}$ & .09 & .08 & $.15^{*}$ & $.22 * *$ & .12 & $.21 * *$ & $.17^{*}$ & .10 & $.19^{* *}$ & $.23^{* *}$ & .13 & $.30^{* *}$ & 1 \\
\hline $6 \mathrm{~b}$ Quality of social contact & $.24 * *$ & .12 & $.19^{* *}$ & $.23^{* *}$ & $.15^{*}$ & .09 & .07 & .06 & .05 & .08 & $.16^{*}$ & $.21 * *$ & $.31^{* *}$ & .07 & $.21 * *$ & $.20^{* *}$ & $.19 * *$ & $.23 * *$ & $.17^{*}$ & $.22 * *$ & $.16^{*}$ & $.26 * *$ & $.32 * *$ & $.22^{* *}$ & $.21 * *$ & $.27^{* * *}$ & $.29 * *$ & $.32 * *$ & \\
\hline
\end{tabular}

** The correlation is significant at the 0.01 level (two-tailed)

* The correlation is significant at the 0.05 level (two- tailed)

Source: Authors' estimations. 
Table 5. Comparison of Linear and Non-linear Models (Vocational and Master Craftsman Scholars, $N=\emptyset 200$ )

\begin{tabular}{|c|c|c|c|c|c|c|c|}
\hline & Job feature & $\begin{array}{l}r_{s} \text { with } \\
\text { job satis- } \\
\text { faction }\end{array}$ & $\begin{array}{l}r_{s} \text { trans- } \\
\text { formed } \\
\text { (AD) }\end{array}$ & $\begin{array}{l}r_{s} \text { low } \\
\text { (AD) }\end{array}$ & $\begin{array}{l}r_{s} \text { high } \\
\text { (AD) }\end{array}$ & $\begin{array}{l}\text { linear } \\
\text { regres- } \\
\text { sion } R^{2}\end{array}$ & $\begin{array}{l}\text { non- } \\
\text { linear } \\
\text { regres- } \\
\text { sion } R^{2} \\
\end{array}$ \\
\hline \multirow[t]{17}{*}{$\mathrm{CE}$} & 2b New learning & $.25^{* *}$ & & & & .203 & .212 \\
\hline & $3 \mathrm{c}$ Task coherence & $.25 * *$ & & & & .178 & .188 \\
\hline & 3f Emotional dissonance & $.38 * *$ & & & & .296 & .297 \\
\hline & 7a Pay level & $.17^{*}$ & & & & .104 & .104 \\
\hline & 8a Pleasant environment & $.20^{* *}$ & & & & .080 & .101 \\
\hline & $8 \mathrm{~b}$ Safe work practices & $.15^{*}$ & & & & .094 & .097 \\
\hline & $8 \mathrm{c}$ Adequate equipment & $.25^{* *}$ & & & & .126 & .126 \\
\hline & 9a Value to society & $.37 * *$ & & & & .078 & .079 \\
\hline & 9b Significance to self & $.44 * *$ & & & & .198 & .199 \\
\hline & 10a Supervision behaves considerately & $.34 * *$ & & & & .255 & .255 \\
\hline & $10 \mathrm{~b}$ Supervision is supportive & $.30 * *$ & & & & .249 & .249 \\
\hline & 11a Job security & $.25 * *$ & & & & .063 & .064 \\
\hline & $11 \mathrm{~b}$ Good future prospects & $.31 * *$ & & & & .172 & .173 \\
\hline & 12a Fair treatment of employees & $.33 * *$ & & & & .261 & .281 \\
\hline & $12 \mathrm{~b}$ Organizations morality in society & $.39 * *$ & & & & .225 & .244 \\
\hline & 3d Conflict between job demands & $.18^{*}$ & & & & .104 & .108 \\
\hline & 3e Work-home conflict & $.20^{* *}$ & & & & .136 & .173 \\
\hline \multirow[t]{11}{*}{$\mathrm{AD}$} & 1a Task discretion & .12 & $.20^{* *}$ & $.27 * *$ & .06 & .112 & .113 \\
\hline & $1 \mathrm{~b}$ Influence over the wider orga. & $.17^{*}$ & $.24 * *$ & $.29 * *$ & .13 & .105 & .108 \\
\hline & 2a Skill use & $.23 * *$ & $.35^{* *}$ & $.38^{* *}$ & -.11 & .128 & .183 \\
\hline & 3a Number of job demands & .06 & $.27^{* *}$ & $.24 * *$ & $-.22 * *$ & .000 & .128 \\
\hline & 3b Difficulty of job demands & -.02 & $.18^{*}$ & .12 & $-.20^{*}$ & .000 & .040 \\
\hline & 4a Range of different tasks & .05 & $.15^{*}$ & .12 & -.14 & .002 & .067 \\
\hline & 5a Future predictability & .12 & $.25^{* *}$ & $.27^{* *}$ & -.12 & .049 & .077 \\
\hline & $5 \mathrm{~b}$ Clear role requirements & .01 & $.31^{* *}$ & $.30^{* *}$ & $-.24 * *$ & .015 & .079 \\
\hline & 5c Availability of feedback & .03 & $.26^{* *}$ & $.27^{* *}$ & -.07 & .071 & .093 \\
\hline & 6a Amount of social contact & .03 & .12 & .13 & -.05 & .050 & .066 \\
\hline & 6b Quality of social contact & .02 & $.24 * *$ & $.26^{* *}$ & -.11 & .046 & .064 \\
\hline
\end{tabular}

Source: Authors' estimations.

Vocational and master craftsman scholars carrying managerial responsibility often have the opportunity to expand their own abilities and to learn $(2 b)$, have the opportunity to complete a task from beginning to end with a visible result (3c) and recognize the importance of their work for themselves and the company (9b). Executives have more positive values for the aspects conflict between different tasks (3d) and conflict between work and family life (3). They have more influence on the organization as a whole (1b) and greater clarity with regard to the future (without career prospects, 5a). These observed correlations cannot exclusively be attributed to higher levels of job autonomy; thus, there is a significant correlation only when looking at the dummy variables for low values of job autonomy and managerial responsibility (1a, $r_{s}=.17, p<0.05, n=174$ ). In the case of the transformed dummy variables, no significant correlation between management responsibility and job autonomy can be observed. Vocational and master craftsman scholars with a higher education level assess their future prospects better than their peers with lower degrees (11b). For all extrinsic $\mathrm{CE}$ aspects except a pleasant work environment and safe work processes, people with a temporary employment contract show lower scores than employees with a permanent contract.
A particularly strong relationship appears between the temporary nature of the employment contract and the assessment of the individual's own future prospects (11b). Self-employed people report more opportunities to develop their own skills and to learn (2b) and have a higher salary (7a). Men report more frequently the possibility to expand their own abilities and to learn (2b), higher job security (11a) and better future prospects operationalized by the following statement: "at present, I am developing in a good direction, towards my personal goals (11b)." The number of employees or the number of seasonal workers shows no significant relationship with the subjective values of the job aspects in this sample.

The personal and structural features examined also show correlations with the preference structure of vocational and master craftsman scholars with respect to the job aspects (Table 7).

For the older respondents in the sample, job autonomy (3c) is more important than it is for their younger classmates. For vocational and master craftsman scholars who carry a form of management responsibility, job autonomy (1a), the impact on the organization (1b) and the importance of their own work for themselves and the company (9b) are more important than they are for their classmates without management responsibility. Instead, they put less value on safe work processes (8b), perhaps 
because they carry out more administrative activities. For people with a temporary contract, it is more important that the employer treats the staff fairly (12a) and that they have safe work processes (8b). Part-time workers put more emphasis on the variety (4a) and the amount of their salary (7a). For self-employed people, it is particularly the job autonomy (1a) and the impact on the organization (1b) that are important. Men place particular emphasis on job autonomy (1a), while women are more concerned about a pleasant work environment (8a) and safe working processes (8b). The number of employees of the company in which the participants work shows no effect on the preferences of the vocational and master craftsman scholars. For pupils from farms with many seasonal workers, the preference is less pronounced in terms of the job aspect appropriate equipment $\left(8 \mathrm{c}, r_{s}=-.15, p<0.05\right.$, $n=196)$.

\section{Results of the Measurement of Preferences for Selected Job Aspects of Students of Horticulture Science}

\section{Sample Description}

In the study from August 2013 to August 2014, the group of students of horticulture science contained more than 200 people, especially from the Leibniz Universität Hannover and the Technical University of Munich. The respondents are on average 25 years old, with an accumulation between 19 and 29 years $(N=212)$.

Table 6. Relationships between Personal and Structural Characteristics and Job Aspects (Vocational and Master Craftsman Scholars)

\begin{tabular}{|c|c|c|c|}
\hline Personal characteristics & Job aspect & Effect size $\left(r_{s}\right)$ & Sample size $(n)$ \\
\hline Age & 8a Pleasant environment & $-.17 *$ & 196 \\
\hline \multirow{15}{*}{ Managerial responsibility } & 2b New learning & $.32 * *$ & 187 \\
\hline & $3 \mathrm{c}$ Task coherence & $.21 * *$ & 187 \\
\hline & 3f Emotional dissonance & $.23 * *$ & 187 \\
\hline & 9b Significance to self & $.26^{* *}$ & 187 \\
\hline & 10a Supervision behave considerate & $.22 * *$ & 187 \\
\hline & 10b Supervision is supportive & $.26 * *$ & 187 \\
\hline & 11a Job security & $.24 * *$ & 187 \\
\hline & $11 \mathrm{~b}$ Good future prospects & $.36^{* *}$ & 187 \\
\hline & 12a Fair treatment of employees & $.23 * *$ & 187 \\
\hline & $12 \mathrm{~b}$ Organizations morality in society & $.17^{*}$ & 200 \\
\hline & $3 \mathrm{~d}$ Conflict between job demands & $.15^{*}$ & 186 \\
\hline & 3e Work-home conflict & $.17 *$ & 186 \\
\hline & $1 b$ Influence over the wider organization & $.21 * *$ & 186 \\
\hline & 2a Skill use & $.18^{*}$ & 186 \\
\hline & 5a Future predictability & $.19 * *$ & 186 \\
\hline Education level & $11 \mathrm{~b}$ Good future prospects & $.27 * *$ & 174 \\
\hline \multirow{8}{*}{ Temporary employment } & $11 \mathrm{~b}$ Good future prospects & $-.40 * *$ & 157 \\
\hline & 3c Task coherence & $-.35 * *$ & 157 \\
\hline & 3f Emotional dissonance & $-.32 * *$ & 157 \\
\hline & 3d Conflict between job demands & $-.32 * *$ & 157 \\
\hline & 1a Task discretion & $-.17^{*}$ & 157 \\
\hline & 1b Influence over the wider organization & $-.18 *$ & 157 \\
\hline & 5a Future predictability & $-.20 *$ & 157 \\
\hline & $5 \mathrm{~b}$ Clear role requirements & $-.19 *$ & 157 \\
\hline \multirow[t]{10}{*}{ Self-employed } & 2b New learning & $.16^{*}$ & 197 \\
\hline & 7a Pay level & $.14^{*}$ & 197 \\
\hline & 9a Value to society & $.21 * *$ & 197 \\
\hline & $11 \mathrm{~b}$ Good future prospects & $.17 *$ & 197 \\
\hline & $3 \mathrm{~d}$ Conflict between job demands & $.16^{*}$ & 197 \\
\hline & 1b Influence over the wider organization & $.21 * *$ & 197 \\
\hline & 3b Difficulty of job demands & $.15^{*}$ & 197 \\
\hline & 5a Future predictability & $.16^{*}$ & 196 \\
\hline & $5 \mathrm{~b}$ Clear role requirements & $.16^{*}$ & 196 \\
\hline & 5c Availability of feedback & $.19 * *$ & 196 \\
\hline \multirow[t]{3}{*}{ Gender $(\mathrm{w}=1, \mathrm{~m}=2)$} & 2b New learning & $.15^{*}$ & 199 \\
\hline & 11a Job security & $.15^{*}$ & 199 \\
\hline & $11 \mathrm{~b}$ Good future prospects & $.16^{*}$ & 199 \\
\hline
\end{tabular}

** The correlation is significant at the 0.01 level (two-tailed)

* The correlation is significant at the 0.05 level (two-tailed)

Source: Authors' estimations. 
Table 7. Relationships between Personal and Structural Characteristics and Preferences for Job Aspects (Vocational and Master Craftsman Scholars)

\begin{tabular}{|c|c|c|c|}
\hline Personal characteristics & Job aspect & Effect size $\left(r_{s}\right)$ & Sample size $(n)$ \\
\hline \multirow[t]{7}{*}{ Age } & 1a Task discretion & $.27 * *$ & 197 \\
\hline & 1b Influence over the wider organization & $.19 * *$ & 197 \\
\hline & 3b Difficulty of job demands & $.21 * *$ & 197 \\
\hline & 3c Task coherence & $.16^{*}$ & 197 \\
\hline & 5c Availability of feedback & $.14^{*}$ & 197 \\
\hline & $9 \mathrm{~b}$ Significance to self & $.15^{*}$ & 197 \\
\hline & 8a Pleasant environment & $-.16^{*}$ & 197 \\
\hline \multirow[t]{5}{*}{ Managerial responsibility } & 1a Task discretion & $.25 * *$ & 174 \\
\hline & $1 \mathrm{~b}$ Influence over the wider organization & $.15^{*}$ & 174 \\
\hline & 3b Difficulty of job demands & $.16^{*}$ & 174 \\
\hline & 9b Significance to self & $.17 *$ & 174 \\
\hline & $8 \mathrm{~b}$ Safe work practices & $.16^{*}$ & 174 \\
\hline \multirow[t]{6}{*}{ Temporary employment } & 12a Fair treatment of employees & $.18^{*}$ & 157 \\
\hline & $8 \mathrm{~b}$ Safe work practices & $.18^{*}$ & 157 \\
\hline & 3b Difficulty of job demands & $-.24 * *$ & 157 \\
\hline & 3a Number of job demands & $-.21 *$ & 157 \\
\hline & $1 \mathrm{~b}$ Influence over the wider organization & $-.17 *$ & 157 \\
\hline & 1a Task discretion & $-.29 * *$ & 157 \\
\hline \multirow[t]{4}{*}{ Part-time employment } & 4a Range of different tasks & $.20 *$ & 160 \\
\hline & $5 \mathrm{~b}$ Clear role requirements & $.25 * *$ & 160 \\
\hline & 5c Availability of feedback & $.16^{*}$ & 160 \\
\hline & 7a Pay level & $.19^{*}$ & 160 \\
\hline \multirow[t]{4}{*}{ Self-employed } & 1a Task discretion & $.18 * *$ & 198 \\
\hline & 1b Influence over the wider organization & $.20 * *$ & 198 \\
\hline & 3a Number of job demands & $.20 * *$ & 198 \\
\hline & 3b Difficulty of job demands & $.19 * *$ & 198 \\
\hline \multirow[t]{3}{*}{ Gender $(\mathrm{w}=1, \mathrm{~m}=2)$} & 1a Task discretion & $.19 * *$ & 200 \\
\hline & 8a Pleasant environment & $-.21 * *$ & 200 \\
\hline & $8 \mathrm{~b}$ Safe work practices & $-.17 *$ & 200 \\
\hline
\end{tabular}

** The correlation is significant at the 0.01 level (two-tailed)

* The correlation is significant at the 0.05 level (two-tailed)

Source: Authors' estimations.

Of the students participating in the study, $55 \%$ have not previously worked in a horticultural company $(N=224)$. For the remaining $45 \%$, the employment duration is on average 19 months $(N=98)$. More than half (53\%,N=225) of the surveyed horticulture students are female. The majority wants to be employed full-time ( $77 \%, N=220)$ with a permanent contract $(93 \%, N=220)$ and to belong to the core workforce of the company (96\%, $N=220$ ) in the future. In their future "dream job," $37 \%$ of the horticulture students think about being self-employed $(N=223)$. A majority of the participants are following the bachelor's program (80\%) or the master's program (16\%) and $4 \%$ are currently completing doctoral studies $(N=224)$. The first semester is clearly overrepresented in the sample.

Preferences of the Students Concerning the Examined Job Aspects

The students were asked only about their preferences regarding the 28 job aspects. For this purpose, the study participants were required to imagine their dream job. The respondents were then asked to rate the importance of every job aspect of this dream job on a 6-point Likert scale (from 1 =unimportant to $6=$ essential). Fig. 5 shows the mean values as a result of this task $(N=\varnothing 204$, standard deviation between 1.0 and 1.2).

The most important point for the surveyed students is that the prospective employer treats its employees fairly. Secondly, the compatibility of work and family (free time) followed by the emotional dissonance operationalized by the statement "in my work I can be completely me, without having to shed my skin" can be found. In the fourth and fifth places we find considerate and supportive leadership. As high on the list as the sixth and seventh places there are two classic job characteristics, job security and a pleasant work environment (buildings, rooms, noise and temperature). The salary can be found only in the lower middle in the eighteenth place, even after job autonomy (17) and the employer's treatment of society as a whole (10). As the most insignificant aspect by far, students assess the difficulty of the tasks in their future job. Other job aspects are also rather insignificant: using one's own skills and experience, developing one's own abilities and the number of tasks. 
12a Fair treatment of employees 3e Work-home conflict

$3 \mathrm{f}$ Emotional dissonance

10a S.vision behaves considerately $10 \mathrm{~b}$ Supervision is supportive 11a Job security

8a Pleasant environment $6 \mathrm{~b}$ Quality of social contact $8 \mathrm{c}$ Adequate equipment $12 b$ Orga. morality in society $9 \mathrm{~b}$ Significance to self $3 \mathrm{c}$ Task coherence

$11 \mathrm{~b}$ Good future prospects $5 \mathrm{~b}$ Clear role requirements $5 \mathrm{c}$ Availability of feedback

$8 b$ Safe work practices

1a Task discretion 7a Pay level

9a Value to society

4a Range of different tasks

$3 \mathrm{~d}$ Conflict between job demands

6a Amount of social contact $1 \mathrm{~b}$ Influence over the wider orga.

5a Future predictability

3a Number of job demands $2 \mathrm{~b}$ New learning 2a Skill use

3b Difficulty of job demands

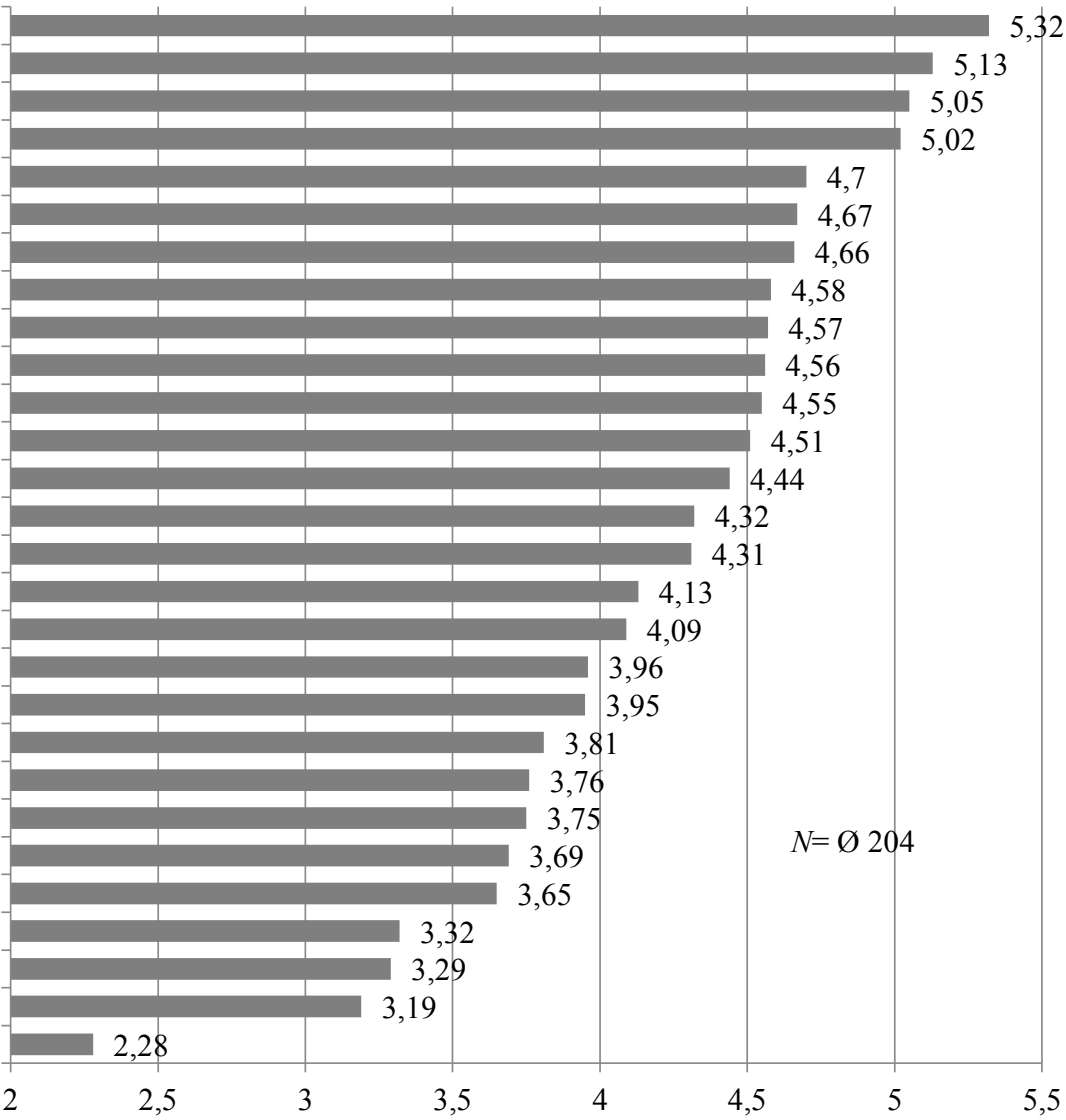

Fig 5 Preferences regarding the job characteristics (students). Source: Authors' estimations.

\section{Impact of Personal and Structural Characteristics on the Preferences Regarding the Job Aspects}

Personal characteristics, such as age, gender or previous practical experience in horticultural companies, have an impact on the individual preferences of the students and are considered in the following section. In addition, other "structural features," such as a possible desire for selfemployment, are included in the analysis (Table 8).

Men prefer to have a high degree of job autonomy in their dream job (1a). In return, the difficulty of the tasks is less important for them (3b). Women prefer the absence of conflicts between different tasks (3d), the reconciliation of work and family (3e) and positive values of emotional dissonance (3f) more than their male counterparts. For students who wish to be employed full-time in their dream job, the amount of salary has a higher value than for students who wish to work part-time (7a). The company's morality in society as a whole, however, is more preferred by those who wish to work part-time (12b). Students who have already worked in a horticultural company pay particular attention to their impact on the organization as a whole (1b), the use of their own skills and experience (2a), safe work processes (8b) and appropriate equipment (8c). Unless the students imagine self-employment in their future dream job, they prefer the job aspect of autonomy, self-determination over job content and implementation (1a), whereas the predictability of the future (5a) and the quality of social contacts play a minor role (6b).

\section{Comparison of the Different Groups}

In the study, 600 complete data sets were analysed. Three heterogeneous groups were studied, each with about 200 full records. The model was tested by performing covariance structure modelling (CSM) with fullinformation maximum likelihood estimation. As the factor loadings of the 28 aspects are mostly above .63 they can be seen as strong (Comrey and Lee, 2013, p. 243), which supports the usage of the measures in the present study. The assumed latent vitamins and job satisfaction showed a reasonable model fit with further potential for improvement (Meyerding, 2015a). The groups of participants considered - employees, vocational and master craftsman scholars and students of horticultural sciences - are distinguished by their different life realities, but also by characteristics such as age, educational background and professional experience. For each group, the results of the preference measurement and the influence of different job aspects on job and life satisfaction were examined. To gain a complete picture of the situation in German horticulture, the results of the three groups need to be compared. For this purpose, Table 9 juxtaposes the results of the various satisfaction and preference measurements. In each case, the sample size, the top five job aspects for the preference measurement (mean values) and the top five aspects in terms of the strength of the relationship between the job aspect and the job satisfaction (Spearman's rho) are shown (see Table 9). 
Table 8. Relationships between Personal and Structural Characteristics and Preferences for Job Aspects (Students)

\begin{tabular}{|c|c|c|c|}
\hline Personal characteristics & Job aspect & Effect size $\left(r_{s}\right)$ & Sample size $(n)$ \\
\hline \multirow[t]{3}{*}{ Age } & 3c Task coherence & $-.15^{*}$ & 195 \\
\hline & 9a Value to society & $-.24 * *$ & 194 \\
\hline & $12 \mathrm{~b}$ Organizations morality in society & $-.16^{*}$ & 194 \\
\hline \multirow[t]{14}{*}{ Gender $(\mathrm{w}=1, \mathrm{~m}=2)$} & 1a Task discretion & $.19 * *$ & 204 \\
\hline & 3b Difficulty of job demands & $-.19 * *$ & 225 \\
\hline & 3d Conflict between job demands & $-.18 *$ & 204 \\
\hline & 3e Work-home conflict & $-.17^{*}$ & 204 \\
\hline & $3 \mathrm{f}$ Emotional dissonance & $-.18^{*}$ & 204 \\
\hline & 4a Range of different tasks & $-.16^{* *}$ & 204 \\
\hline & $5 \mathrm{~b}$ Clear role requirements & $-.21 * *$ & 204 \\
\hline & 5c Availability of feedback & $-.15^{* *}$ & 203 \\
\hline & $8 \mathrm{~b}$ Safe work practices & $-.22 * *$ & 203 \\
\hline & 8c Adequate equipment & $-.14^{*}$ & 203 \\
\hline & 10a Supervision behave considerate & $-.16^{*}$ & 203 \\
\hline & $10 \mathrm{~b}$ Supervision is supportive & $-.20 *$ & 203 \\
\hline & 12a Fair treatment of employees & $-.19 * *$ & 203 \\
\hline & 12b Organizations morality in society & $-.17^{*}$ & 203 \\
\hline \multirow[t]{4}{*}{ Wish to work full-time } & 7a Pay level & $.22 * *$ & 203 \\
\hline & $8 \mathrm{~b}$ Safe work practices & $.18 * *$ & 203 \\
\hline & $8 \mathrm{c}$ Adequate equipment & $.17^{*}$ & 203 \\
\hline & $12 \mathrm{~b}$ Organizations morality in society & $-.16^{*}$ & 203 \\
\hline \multirow[t]{4}{*}{ Progress in study } & 2a Skill use & $.19 * *$ & 224 \\
\hline & 4a Range of different tasks & $.17 *$ & 204 \\
\hline & $3 \mathrm{c}$ Task coherence & $-.16^{*}$ & 204 \\
\hline & 12b Organizations morality in society & $-.15^{*}$ & 203 \\
\hline \multirow[t]{6}{*}{ Work experience } & 1a Task discretion & $.22 * *$ & 204 \\
\hline & 2a Skill use & $.21 * *$ & 224 \\
\hline & 2b New learning & $.18 * *$ & 224 \\
\hline & 3b Difficulty of job demands & $.17^{*}$ & 224 \\
\hline & $8 \mathrm{~b}$ Safe work practices & $.14^{*}$ & 203 \\
\hline & 8c Adequate equipment & $.15^{*}$ & 203 \\
\hline \multirow[t]{8}{*}{ Length of work experience } & 1b Influence over the wider orga. & $-.22 *$ & 95 \\
\hline & 8a Pleasant environment & $-.24 *$ & 94 \\
\hline & $8 \mathrm{~b}$ Safe work practices & $-.24 *$ & 94 \\
\hline & 9a Value to society & $-.30 * *$ & 94 \\
\hline & $10 \mathrm{~b}$ Supervision is supportive & $-.21 *$ & 94 \\
\hline & 11a Job security & $-.21 *$ & 94 \\
\hline & 12a Fair treatment of employees & $-.23 *$ & 94 \\
\hline & 12b Organizations morality in society & $-.29 * *$ & 94 \\
\hline \multirow[t]{3}{*}{ Prefer temporary contract } & 3b Difficulty of job demands & $.15^{*}$ & 220 \\
\hline & 7a Pay level & $-.14 *$ & 203 \\
\hline & $11 \mathrm{~b}$ Good future prospects & $-.15^{*}$ & 203 \\
\hline \multirow[t]{3}{*}{ Imagine self-employment } & 1a Task discretion & $.36 * *$ & 204 \\
\hline & 5a Future predictability & $-.20 * *$ & 204 \\
\hline & 6b Quality of social contact & $-.14 *$ & 203 \\
\hline
\end{tabular}

** The correlation is significant at the 0.01 level (two-tailed)

* The correlation is significant at the 0.05 level (two-tailed)

Source: Authors' estimations.

For all three groups, the job feature related to the fair treatment of the employees shows the strongest preference values. The employees favour in the second place the opportunity to learn new skills, followed by considerate leadership, the use of their own abilities and low emotional dissonance.

For the vocational and master craftsman scholars, emotional dissonance and the possibility to learn new skills can be found in the second and third places. In the fourth place is suitable equipment and ranked fifth is the conflict between work and family. At this point, it is clear that work issues such as emotional dissonance and the conflict between work and family, which show changes in work attitudes and preference structure that require a cultural change within the company, gain importance. The younger generation with a formal higher education level shows a change in work attitude and favours job aspects that are accompanied by an increased work-life balance.

The trend described above is also reflected in the students' results. Here, the conflict between work and 
family is as high as the second place in the most important work characteristics, followed by emotional dissonance, that is, the ability to be completely oneself at work. Ranked fourth and fifth we find considerate executives and supportive executives. From the results, it can be deduced that for young well-trained junior staff, a worklife balance and transformational employee-oriented leadership are particularly important and that horticultural companies need to change their business and particularly their management culture to be attractive employers for the new generation (Y).

Overall, for all the groups studied, it is particularly important that the employer deals fairly with its employees, that they do not have to adjust too much at work (emotional dissonance), that they are able to develop their skills, that there is as little conflict between work and family as possible, that they can use their skills, that adequate equipment is available and that their leadership maintains supportive, considerate behaviour. It is interesting that the availability of the appropriate equipment has such a high priority. This result is not commonly observed in other industries (Salvendy, 2012) and indicates the high level of physical stress in horticulture.

The strongest influence on job satisfaction for the group of employees is shown by the job aspect good future prospects. Ranked second, there are three aspects: suitable equipment, the fairness of the employer towards its employees and the conflict between work and family. In third place is supportive leadership and in fourth place the value of the work for oneself and the fairness of the employer towards society. Emotional dissonance and considerate leadership find themselves in fifth place. Particularly for this group good future prospects stand out, underlining the importance for employees to have the feeling of moving in a positive direction (towards their personal goals). The appropriate equipment plays a strong role in horticulture; this result seems to be a special characteristic of the industry.

For the group of vocational and master craftsman scholars, the strongest connection can be observed with the characteristic values of the work feature emotional dissonance. In the second and third places, considerate and supporting leadership can be found, followed by the fairness of the employer towards its employees and to society as a whole, that is, to customers, suppliers and the environment.

These results indicate that the sustainability of the horticultural company positively affects employee satisfaction (and/or vice versa). Furthermore, they provide an indication that soft job aspects, which include a special form of corporate and leadership culture, have the greatest effect on employee satisfaction, particularly among younger, well-trained employees. The results also show that the influence of "hard" job aspects, such as the salary, the difficulty of the tasks, the variety and the job security, is not especially great.

Table 9. Comparison of the Results for the Three Different Groups

\begin{tabular}{|c|c|c|c|}
\hline Group & Employees & $\begin{array}{l}\text { Vocational and master } \\
\text { craftsman scholars }\end{array}$ & Students \\
\hline Average age & 35 years & 24 years & 25 years \\
\hline $\begin{array}{l}\text { Sample size } \\
\text { preferences }\end{array}$ & 337 & 205 & 204 \\
\hline \multirow[t]{5}{*}{ Preferences top 5} & 12a Fair treatment of employees (5.13) & $\begin{array}{l}\text { 12a Fair treatment of } \\
\text { employees }(5.21)\end{array}$ & $\begin{array}{l}\text { 12a Fair treatment of } \\
\text { employees }(5.32)\end{array}$ \\
\hline & 2b New learning (5.08) & $\begin{array}{l}\text { 3f Emotional dissonance } \\
(5.11)\end{array}$ & $\begin{array}{l}\text { 3e Work/home conflict } \\
\text { (5.13) }\end{array}$ \\
\hline & 10a Considerate supervisor (4.99) & 2b New learning (5.07) & $\begin{array}{l}\text { 3f Emotional } \\
\text { dissonance }(5.05)\end{array}$ \\
\hline & 2a Skill use (4.98) & $\begin{array}{l}\text { 8c Adequate equipment } \\
(4.98)\end{array}$ & $\begin{array}{l}\text { 10a Considerate } \\
\text { supervisor }(5.02)\end{array}$ \\
\hline & 3f Emotional dissonance (4.90) & $\begin{array}{l}\text { 3e Work/home conflict } \\
\text { (4.91) }\end{array}$ & $\begin{array}{l}\text { 10b Supportive } \\
\text { supervision }(4.70)\end{array}$ \\
\hline \multirow{6}{*}{$\begin{array}{l}\text { Sample size } \\
\text { Effect on job } \\
\text { satisfaction top } 5\end{array}$} & 229 & 200 & $\mathrm{~N} / \mathrm{A}$ \\
\hline & $11 \mathrm{~b}$ Good future prospects $(.62 * *)$ & $\begin{array}{l}3 \mathrm{f} \text { Emotional dissonance } \\
(.52 * *)\end{array}$ & $\mathrm{N} / \mathrm{A}$. \\
\hline & $\begin{array}{l}8 \mathrm{c} \text { Adequate equipment }\left(.51^{* *}\right), 12 \mathrm{a} \\
\text { Fair treatment of employees }\left(.51^{* *}\right), 3 \mathrm{e} \\
\text { Work/home conflict }\left(.51^{* *}\right)\end{array}$ & $\begin{array}{l}10 \mathrm{a} \text { Considerate supervisor } \\
\left(.50^{* *}\right)\end{array}$ & $\mathrm{N} / \mathrm{A}$. \\
\hline & 10b Supportive supervision $(.50 * *)$ & $\begin{array}{l}\text { 10b Supportive } \\
\text { supervision }\left(.49^{* *}\right)\end{array}$ & $\mathrm{N} / \mathrm{A}$. \\
\hline & $\begin{array}{l}\text { 9b Significance to self }(.49 * *), 12 b \\
\text { Moral organization }\left(.49^{* *}\right)\end{array}$ & $\begin{array}{l}\text { 12a Fair treatment of } \\
\text { employees }\left(.48^{* *}\right)\end{array}$ & $\mathrm{N} / \mathrm{A}$. \\
\hline & $\begin{array}{l}\text { 3f Emotional dissonance }(.50 * *), 10 \mathrm{a} \\
\text { Supervision behaves considerately } \\
(.50 * *)\end{array}$ & $\begin{array}{l}\text { 12b Moral organization } \\
\left(.45^{* *}\right)\end{array}$ & $\mathrm{N} / \mathrm{A}$. \\
\hline
\end{tabular}


Furthermore, the characteristic values of the twelve job features could affect the satisfaction of the employee and at the same time his ability to achieve a high performance level. For example, supportive leadership (job feature 10) increases the satisfaction of employees and at the same time creates the conditions for a high working capacity. In this case, higher characteristic values of supportive leadership lead to increased job satisfaction and performance (Lyubomirsky, King and Diener, 2005).

As the requirements for job satisfaction and work performance are mostly moderate characteristic values of job features, the employee satisfaction survey is a tool for both enhancing satisfaction and optimizing the use of human capital and thus serving the company's profitability. For horticultural companies, in which the personnel costs account for $40 \%$ of the total costs, this optimization potential of human resource management is particularly interesting, especially since so far not enough importance has been attached to these issues.

There is a possibility that the utility functions of the job characteristics apply equally to the employees' performance and to satisfaction, so that the optimum for satisfaction is close to the optimum for the long-term utilization of the performance potential of each employee. For example, stretched and excessive demand could lead to both dissatisfaction and long-term suboptimal performance. This possibility of using the vitamin model has not yet been investigated empirically.

\section{CONCLUSION}

The data support Warr's (2007) vitamin model and the assumption of non-linear relationships between job characteristic values and job satisfaction. Furthermore, the personal characteristics of the study participants are included in the analysis. The study indicates a change in the preference structure of employees, who in the future would prefer a good work-life balance in particular as well as other "soft" factors.

\section{REFERENCES}

ADAMS, J. S. (1963): Towards an understanding of inequity. The Journal of Abnormal and Social Psychology, 67, p. 422-436. DOI: http://dx.doi.org/10.1037/h0040968 BACKHAUS, K., ERICHSON, B., WEIBER, R. (2013): Fortgeschrittene multivariate Analysemethoden: Eine anwendungsorientierte Einführung (2nd ed.). Berlin: Springer Gabler.

BARRICK, M. R., MOUNT, M. K. (1991): The Big Five Personality Dimensions And Job Performance: A MetaAnalysis. Personnel Psychology, 44, p. 1-26. DOI: 10.1111/j.1744-6570.1991.tb00688.x

BITSCH, V., HOGBERG, M. (2005): Exploring Horticultural Employees' Attitudes Toward Their Jobs: A Qualitative Analysis Based on Herzberg's Theory of Job Satisfaction. Journal of Agricultural and Applied Economics, 37(03), p. 659-671. DOI: $\underline{10.1017 / \mathrm{S} 1074070800027152}$
BURGER, J. M. (1989): Negative reactions to increases in perceived personal control. Journal of Personality and Social Psychology, 56, p. 246-256. DOI: http://dx.doi.org/10.1037/0022-3514.56.2.246

CAPLAN, R. D. (1975): Job Demands and Worker Health: Main Effects and Occupational Differences: U.S. Department of Health, Education, and Welfare, Public Health Service, Center for Disease Control. New York: National Institute for Occupational Safety and Health,.

CARLOPIO, J. R. (1996): Construct validity of a physical work environment satisfaction questionnaire. Journal of Occupational Health Psychology, 1, p. 330-344.

COMREY, A. L., LEE, H. B. (2013): A First Course in Factor Analysis (2nd ed.). Hoboken: Taylor and Francis. CLASSEN, M., KYAW, F. von. (2007): Change Management-Studie 2008: Business Transformation Veränderungen erfolgreich gestalten. Berlin: Capgemini. CROPANZANO, R., BOWEN, D. E., GILLILAND, S. W. (2007): The Management of Organizational Justice. Briarcliff: Manor.

DEELSTRA, J. T., PEETERS, M. C. W., SCHAUFELI, W. B., STROEBE, W., ZIJLSTRA, F. R. H., VAN DOORNEN, L. P. (2003): Receiving instrumental support at work: When help is not welcome. Journal of Applied Psychology, 88, p. 324-331. DOI: 10.1037/00219010.88.2.324

DIAMANTOPOULOS, A. (1994): Modelling with LISREL: A guide for the uninitiated. Journal of Marketing Management, 10, p. 105-136. DOI: 10.1080/0267257X.1994.9964263

DIENER, E., SUH, M. E. (1998): Subjective well-being and age: An international analysis. Annual review of gerontology and geriatrics: Vol. 17. Focus on emotion and adult development. SCHAIE, K. W., LAWTON, M. P. (Eds). New York, N.Y: Springer Pub. Co.

DODGE, R., DALY, A., HUYTON, J., SANDERS, L. (2012). The challenge of defining wellbeing. International Journal of Wellbeing, 2, p. 222-235. DOI: 10.5502/ijw.v2i3.4

FIELD, A. P. (2009): Discovering statistics using SPSS. Introducing statistical methods. Los Angeles, London: Sage Publications.

FRESE, M., ZAPF, D. (1999): On the importance of the objective environment in stress and attribution theory. Counterpoint to Perrewé and Zellars. Journal of Organizational Behavior, 20, p. 761-765. DOI: 10.1002/(SICI)1099-1379(199909)20:5<761::AID-

\section{JOB951>3.0.CO;2-Y}

FRIED, Y., SLOWIK, L. H., BEN-DAVID, H. A., TIEGS, R. B. (2001): Exploring the relationship between workspace density and employee attitudinal reactions: An integrative model. Journal of Occupational and Organizational Psychology, 74, p. 359-372. DOI: $\underline{10.1348 / 096317901167406}$

GANZACH, Y. 1998. Intelligence and Job Satisfaction. The Academy of Management Journal, 41: 526-539. DOI: $10.2307 / 256940$

GLAZER, S., BEEHR, T. A. (2005): Consistency of implications of three role stressors across four countries. Journal of Organizational Behavior, 26, p. 467-487. DOI: $\underline{10.1002 / j o b .326}$ 
GLOMB, T. M., KAMMEYER-MUELLER, J. D., ROTUNDO, M. (2004): Emotional Labor Demands and Compensating Wage Differentials. Journal of Applied Psychology, 89, p. 700-714. DOI: 10.1037/0021$\underline{9010.89 .4 .700}$

GRANDEY, A., CORDEIRO, B., CROUTER, A. (2005): A longitudinal and multi-source test of the work-family conflict and job satisfaction relationship. Journal of Occupational and Organizational Psychology, 78, p. 305323. DOI: $10.1348 / 096317905 \times 26769$

GREENHAUS, J. H., BEUTELL, N. J. (1985): Sources of Conflict Between Work and Family Roles. Academy of Management Review, 10, p. 76-88. DOI: 10.5465/AMR.1985.4277352

GURRATH, P. (2006): Ergebnisse der Gartenbauerhebung 2005. Wirtschaft und Statistik, 10, p. 1037-1047.

HACKMAN, R. J., OLDHAM, G. R. (1975): Development of the Job Diagnostic Survey. Journal of Applied Psychology, 60, p. 159-170.

HERZBERG, F. (1966): Work and the nature of man. New York: Thomas Y. Crowell.

HERZBERG, F., MAUSNER, B., SYNDERMAN, B. B. (1959): The motivation to work (2nd ed.). New York: Wiley.

JONG, J. de, SCHAUFELI, W. B. (1998): Job characteristics and employee well-being: a test of Warr's Vitamin Model in health care workers using structural equation modelling. Journal of Organizational Behavior, 19 , p. $387-407$. DOI: $10.1002 /(\mathrm{SICI}) 1099-$ 1379(199807)19:4<387::AID-JOB851>3.0.CO;2-9

KARASEK, R. A., JR. (1979): Job Demands, Job Decision Latitude, and Mental Strain: Implications for Job Redesign. Administrative Science Quarterly, 24, p. 285308. DOI: $\underline{10.2307 / 2392498}$

KORNHAUSER, A. (1962): Toward an Assessment of the Mental Health of Factory Workers: A Detroit Study. Human Organization, 21, p. 43-46.

KUNIN, T. (1955): The construction of a new type of attitude measure. Personnel Psychology, 8, p. 65-77.

LEWIN, K., DEMBO, T., FESTINGER, L., SEARS, P. S. (1944): Level of Aspiration. Personality and Behavior Disorders M. HUNT (Eds.) New York: Roland Press.

LYUBOMIRSKY, S., KING, L., DIENER, E. (2005): The Benefits of Frequent Positive Affect: Does Happiness Lead to Success? Psychological Bulletin, 131, p. 803-855. DOI: $10.1037 / 0033-2909.131 .6 .803$

MCCOY, J. M., EVANS, G. W. (2005): Physical work environment. Handbook of work stress J. BARLING, M. R. FRONE, E. K. KELLOWAY (Eds.) Thousand Oaks, Calif: Sage Publications.

MEYERDING, S. G. H. (2015a): Job characteristics and job satisfaction: A test of Warr's vitamin model in German horticulture. The Psychologist-Manager Journal, 18, p. 86-107. DOI: $10.1037 / \mathrm{mgr} 0000029$

MEYERDING, S. (2015b): Mitarbeiterzufriedenheit als Kernindikator sozialer Nachhaltigkeit. Thünen Report 22. Aktuelle Forschung in der Gartenbauökonomie; Tagungsband zum 1. Symposium für Ökonomie im Gartenbau. am 27. November 2013 in der Paulinerkirche Göttingen W. DIRKSMEYER, L. THEUVSEN, M.
KAYSER (Eds.) Braunschweig: Johann Heinrich von Thünen-Institut.

MONTÉN, A. (2011): Arbeitskräftemigration in Europa: Es könnten viele kommen. Der ifo Wirtschaftskompass. Zahlen - Fakten - Hintergründe G. MILBRADT, G. NERB, W. OCHEL, H.-W. SINN (Eds.) München: Hanser, Carl.

REICHE, S., SPARKE, K. (2012): Managing Job Commitment of young Professionals in Germany's green Industry. DGG-Proceedings, 2, p. 1-5.

REINECKE, J. (2005): Strukturgleichungsmodelle in den Sozialwissenschaften. München: Oldenbourg.

RICE, R. W., FRONE, M. R., Mcfarlin, D. B. (1992): Work-nonwork conflict and the perceived quality of life. Journal of Organizational Behavior, 13, p. 155-168. DOI: $\underline{10.1002 / j o b .4030130205}$

ROSENSTIEL, L. von, KEHR, H. M., MAIER, G. W. (2000): Motivation and Volition in Pursuing Personal Work Goals. Motivational psychology of human development. Developing motivation and motivating development J. HECKHAUSEN (Eds.) Amsterdam, Netherlands; New York: North-Holland; Elsevier.

SALCHER, E. F., HOFFELT, P. (1995): Psychologische Marktforschung (2nd ed.). Berlin: Walter de Gruyter.

SALVENDY, G. (2012): Handbook of human factors and ergonomics (4th ed.). Hoboken: John Wiley \& Sons.

SCHREINER, M., ALTMANN, M., STENGER, M., KORN, M., DIRKSMEYER, W., LUDWIG-OHM, S. ... (2013): Zukunftsstrategie Gartenbau: Abschlussbericht zum Zukunftskongress Gartenbau am 11./12. September 2013 in Berlin. Bonn.

SIBBALD, B. (2003): National survey of job satisfaction and retirement intentions among general practitioners in England. BMJ, 326: 22. DOI: 10.1136/bmj.326.7379.22 SPREITZER, G., SUTCLIFFE, K., DUTTON, J., SONENSHEIN, S., GRANT, A. M. (2005): A Socially Embedded Model of Thriving at Work. Organization Science, 16, p. 537-549. DOI: 10.1287/orsc.1050.0153

SRIVASTAVA, A., LOCKE, E. A., BARTOL, K. M. (2001): Money and subjective well-being: It's not the money, it's the motives. Journal of Personality and Social Psychology, 80, p. 959-971.

TABER, T. D., BEEHR, T. A., WALSH, J. T. (1985): Relationships between job evaluation ratings and selfratings of job characteristics. Organizational Behavior and Human Decision Processes, 35, p. 27-45. DOI: 10.1016/0749-5978(85)90043-3

THOMPSON, S. C. (2009): The Role of Personal Control in Adaptive Functioning. Oxford handbook of positive psychology, C. R. SNYDER \& S. J. LOPEZ (Eds.) Oxford, New York: Oxford University Press.

THORSTEINSON, T. J. (2003): Job attitudes of part-time vs. full-time workers: A meta-analytic review. Journal of Occupational and Organizational Psychology, 76, p. 151177. DOI: $10.1348 / 096317903765913687$

VAN VEGCHEL, N., JONGE, J. DE, \& LANDSBERGIS, P. A. (2005): Occupational stress in (inter)action: the interplay between job demands and job resources. Journal of Organizational Behavior, 26, p. 535-560. DOI: $\underline{10.1002 / j o b .327}$ 
WARR, P. (1987): Work, unemployment and mental health. Oxford science publications. Oxford: Oxford Univ. Pr.

WARR, P. (1990): Decision latitude, job demands, and employee well-being. Work \& Stress, 4, p. 285-294. DOI: $\underline{10.1080 / 02678379008256991}$

WARR, P. (1994): A conceptual framework for the study of work and mental health. Work \& Stress, 8, p. 84-97. DOI: $\underline{10.1080 / 02678379408259982}$

WARR, P. (2012): How to think about and measure psychological well-being. In R. R. SINCLAIR, M. WANG, L. E. TETRICK (Eds.), Research methods in occupational health psychology. Measurement, design, and data analysis (pp. 76-90). New York: Psychology Press.

WARR, P. (2013): Jobs and job-holders: Two sources of happiness and unhappiness. In S. A. DAVID (Eds.) The Oxford handbook of happiness, Oxford: Oxford Univ. Press.
WARR, P. B. (2007): Work, happiness, and unhappiness. Mahwah, N.J: Lawrence Erlbaum Associates.

WEIBER, R., MÜHLHAUS, D. (2014): Strukturgleichungsmodellierung: Eine anwendungsorientierte Einführung in die Kausalanalyse mit Hilfe von AMOS, SmartPLS und SPSS. Berlin, Heidelberg: Springer Gabler.

WRZESNIEWSKI, A., MCCAULEY, C., ROZIN, P., SCHWARTZ, B. (1997): Jobs, careers, and callings: People's relations to their work, Journal of Research in Personality, 31, p. 21-33. DOI: 10.1006/jrpe.1997.2162 WYATT, S. LANGDEN, J. N. (1938): The machine and the worker: A study of machine-feeding processes. London: Industrial Health Research Board. 